NASA Technical Memorandum 106307

AIAA-93-2392

\title{
Low Power Arcjet System Spacecraft Impacts
}

Eric J. Pencil and Charles J. Sarmiento

Lewis Research Center

Cleveland, Ohio

and

D.A. Lichtin, J.W. Palchefsky, and A.L. Bogorad

Martin Marietta Astro Space

Princeton, New Jersey

Prepared for the 29th Joint Propulsion Conference and Exhibit cosponsored by the AIAA, SAE, ASME, and ASEE Monterey, California, June 28-30, 1993

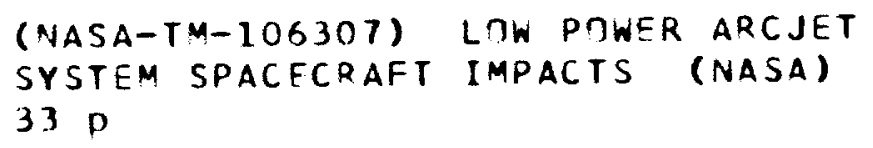

N94-17856

Unclas 


\title{
LOW POWER ARCJET SYSTEM SPACECRAFT IMPACTS
}

\author{
Eric J. Pencil* and Charles J. Sarmiento** \\ NASA Lewis Research Center \\ Cleveland, $\mathrm{OH} 44135$
}

\author{
D. A. Lichtint, J. W. Palchefsky $\dagger \dagger$, and A. L. Bogorad $\dagger \dagger \dagger$ \\ Martin Marietta Astro Space \\ Princeton, NJ 08543
}

\begin{abstract}
Application of electrothermal arcjets on communications satellites requires assessment of integration concerns identified by the user community. Perceived risks include plume contamination of spacecraft materials, induced arcing or electrostatic discharges between differentially charged spacecraft surfaces, and conducted and radiated electromagnetic interference (EMI) for both steady state and transient conditions. A Space Act agreement between Martin Marietta Astro Space, the Rocket Research Company, and NASA's Lewis Research Center was established to experimentally examine these issues. Spacecraft materials were exposed to an arcjet plume for 40 hours, representing 40 weeks of actual spacecraft life, and contamination was characterized by changes in surface properties. With the exception of the change in emittance of one sample, all measurable changes in surface properties resulted in acceptable end of life characteristics. Charged spacecraft samples were benignly and consistently reduced to ground potential during exposure to the powered arcjet plume, suggesting that the arcjet could act as a charge control device on spacecraft. Steady state EMI signatures obtained using two different power processing units were similar to emissions measured in a previous test. Emissions measured in UHF, S, C, Ku and $K a$ bands obtained a null result which verified previous work in the UHF, $S$, and $C$ bands. Characteristics of conducted and radiated transient emissions appear within standard spacecraft susceptibility criteria.

Nomenclature

A Area of solar cell array, 128 $\mathrm{cm}^{2}$

AF Antenna factor, $\mathrm{dB} / \mathrm{m}$

BB Broadband emission level at 1 meter, $\mathrm{dB} \mu \mathrm{V} / \mathrm{m} / \mathrm{MHz}$

BNF. Bandwidth normalization factor, $d B$

CL Cable loss, $\mathrm{dB}$

Cs Simulated solar constant, $137.2 \mathrm{~mW} / \mathrm{cm}^{2}$

FF Fill factor, \%

$I_{s c}$ Short circuit current, $\mathrm{mA}$

$I(\lambda)$ Solar spectral irradiance, $\mathrm{mW} /\left(\mathrm{cm}^{2} \mu \mathrm{m}\right)$

NB Narrowband emission level at 1 meter, $\mathrm{dB} / \mu \mathrm{V} / \mathrm{m}$

$P_{\text {input }}$ Input power from solar simulator, $\mathrm{mW}$
\end{abstract}

* Aerospace Engineer, On-Board Propulsion Branch, Member AIAA.

** Electrical Engineer, On-Board Propulsion Branch.

$\dagger$ Principal Hardware Design Engineer, Member AlAA.

$\dagger \dagger$ Principal Development Engineer.

$\dagger \dagger \dagger$ Senior Development Engineer.

Copyright (c) 1993 by the Martin Marietta Corporation. Published by the American Institute of Aeronautics and Astronautics, Inc. with permission. 


\begin{tabular}{|c|c|}
\hline$P_{\max }$ & Maximum solar cell power, \\
\hline $\mathbf{R}$ & Resistance, ohms \\
\hline RB & $\begin{array}{l}\text { Spectrum analyzer resolution } \\
\text { bandwidth ( } 3 \mathrm{~dB} \text { Gaussian), } \\
\mathrm{MHz}\end{array}$ \\
\hline$V_{\text {oc }}$ & Open circuit voltage, $\mathrm{mV}$ \\
\hline$\alpha$ & Absorptance \\
\hline $\boldsymbol{\varepsilon}$ & Emittance \\
\hline$\eta$ & Solar cell efficiency, \% \\
\hline$\lambda$ & Wavelength, $\mu \mathrm{m}$ \\
\hline & Reflectance \\
\hline$p(\lambda)$ & $\begin{array}{l}\text { Reflectance spectral } \\
\text { response }\end{array}$ \\
\hline$\Phi$ & $\begin{array}{l}\text { Spectrum analyzer displaye } \\
\text { voltage, } \mathrm{dB} \mu \mathrm{V} \text { or } \mu \mathrm{V}\end{array}$ \\
\hline
\end{tabular}

\section{Introduction}

Electric propulsion users are concerned with several integration issues including conducted and radiated heat fluxes, plume momentum and contamination impacts, conducted and radiated electromagnetic interference, transmission interference, and spacecraft charging. In addition to component development of a $1 \mathrm{~kW}$ class hydrazine arcjet system,1,2,3 efforts have focused on resolving integration issues associated with north-south stationkeeping applications on geosynchronous communications satellites.

In the recent past, research was directed toward examining characteristics of the arcjet plume. Langmuir probe surveys of the arcjet plume characterized electron number densities and temperatures for various nozzle geometries and operating conditions.4.5.6 It was found that the $1 \mathrm{~kW}$ class arcjet plume is weakly (less than 1\%) ionized.4 These profiles were then used in a source flow model 7 for estimates of the impact on signals transmitted through the far-field plume regions simulating realistic propagation paths. The plume effect on antenna performance was minimal for the $1 \mathrm{~kW}$ class arcjet.7,8
An experimental study of
spacecraft compatibility of an
operational arcjet system was performed by TRW under contract to NASA. A flight-type arcjet system was mounted on a FLTSATCOM qualification model satellite in a large vacuum chamber. 9 Measurement of the radiated and conducted electromagnetic emissions revealed that radiated emissions from the arcjet and its power processor were within acceptable limits above 500 MHz. A low frequency broadband signature exceeded the MIL-STD461C limit below $40 \mathrm{MHz}$. Since communications satellites typically transmit in higher frequency ranges, communications would not be affected by these emissions. Satellite telemetry was monitored during arcjet ignition and no significant changes in signals were noticed. An array of calorimeters located at a distance of $1.8 \mathrm{~m}$ and 2.3 $m$ from the thruster exit measured a maximum heat flux of 0.18 suns. No visible degradation or mass deposition was observed on witness plates placed at various locations in the plume.

A $1.8 \mathrm{~kW}$ hydrazine arcjet system has been baselined for north-south stationkeeping application on the Martin Marietta Series 7000 communications satellites. In order to address residual user integration concerns, an integration test was performed under a Space Act agreement between Martin Marietta Astro Space, formerly General Electric's Astro Space Division; the Rocket Research Company (RRC); and NASA's Lewis Research Center (LeRC). Tests were performed in a large vacuum facility at LeRC using a flight-type arcjet system. Spacecraft material samples and some test instrumentation were provided by Martin Marietta and one of two power processing units (PPU's) was provided by RRC, the 
arcjet system contractor, and Pacific Electro Dynamics (PED), the PPU subcontractor. In this test, plume contamination on spacecraft material samples, electrostatic discharge phenomena, and electromagnetic compatibility were investigated 10 .

Potential contamination of spacecraft surfaces was investigated by positioning spacecraft material samples relative to the arcjet thruster simulating a satellite configuration. Duration of the exposure was 40 hours which represented approximately 40 weeks of satellite lifetime or $6 \%$ of the total thruster operation life. Contamination impacts were quantified via changes in the surface properties of the spacecraft materials. Surface properties of absorptance, emittance, and resistance were measured for the material samples. Effects on a silicon solar array were quantified by measuring the initial and final current-voltage traces.

Another concern was the possibility that ignition of an arcjet and the resultant formation of the weakly ionized plasma plume would induce an elecrostatic discharge (ESD) between charged surfaces and ground. Spacecraft surfaces exposed to the ambient conditions in geosynchronous orbit can build up multi-kilovolt potential differenences between spacecraft surfaces or between spacecraft surfaces and spacecraft ground.11 If the charging voltage exceeds the breakdown threshold, an electrostatic discharge, or spark, can occur. ESD's can cause interference in spacecraft electronics ranging from simple logic switching to complete system failures. Significant long-term degradation of exterior surfaces such as optical solar reflectors may also result from repeated ESD events.12 In order to investigate discharge phenomena, an electron beam gun was used to charge several spacecraft material samples, such as a silicon solar cell array, an optical solar reflector (OSR), and a S13GLO thermal paint sample. Since sample ESD rate can have a direct relationship to the outgassing rate, 13 samples were mounted with adhesives used in satellite manufacturing in order to accurately simulate some outgassing rates. Exposure of charged surfaces to the arcjet plume allowed investigation of the discharge phenomena and possible surface degradation that resulted.

Although issues regarding EMI for an arcjet system in steady state operation were previously addressed, 9 there remained unexamined areas of interest. These included conducted and radiated transients associated with arcjet starting as well as radiated emissions in special communication bands during steady state operation. Selected EMI measurements were, therefore, performed which focused on these untreated issues. For comparison purposes, an attempt was also made to incorporate some overlap with previous investigations 9 by examining low frequency $(<50$ $\mathrm{MHz}$ ) radiated emissions using two different PPU's. An array of antennas was used to measure arcjet radiated emissions in frequency bands which included $50 \mathrm{kHz}$ to 50 $\mathrm{MHz}, 160$ to $500 \mathrm{MHz}$, and special UHF, S, C, Ku, and $\mathrm{Ka}$ bands at a distance of 1 meter from the thruster exit plane. Startup radiated transients were captured using two antennas of the array which were calibrated for a combined 20 to $500 \mathrm{MHz}$ frequency range. Conducted startup transients were characterized using lead-acid batteries instead of a commercial DC power supply as the primary power source for the arcjet system. 
Hardware and Facility

Arcjet System and Interfaces

A flight-type arcjet system consisting of an arcjet thruster, power processing unit (also known as power conditioning unit), and triax interconnect cable was used throughout this test program. The arcjet was operated on $\mathrm{N}_{2}: 2 \mathrm{H}_{2}$ mixtures simulating fully decomposed hydrazine, which eliminated the need for a gas generator. The thruster was a 1 to 2 $\mathrm{kW}$ design developed at RRC under contract to NASA. A cross-sectional view and description of this thruster were reported elsewhere. 14 Two different PPU's were used to run the arcjet during testing. The first unit, PPU A, developed under a prior NASA program by WatkinsJohnson and later modified by PED, was used in previous tests.9 This unit was supplied with $1.4 \mathrm{~kW}$ input power and produced a $1.26 \mathrm{~kW}$ regulated output to the arcjet thruster. PPU A was used in contamination testing and for comparative low frequency EMI measurements. The second unit, PPU B, developed by PED, was an engineering development model used for space qualification testing under a program between Martin Marietta and RRC. PPU $B$ is identical in circuit layout and packaging to the Series 7000 PPU's. This unit converts a maximum input power of $1.8 \mathrm{~kW}$ to a nominal output power of $1.63 \mathrm{~kW}$ at an arcjet operating voltage range of 90 to 140 Vdc. 15 PPU $B$ was used in the EMI and ESD portions of the test.

Figure 1 shows an electrical schematic of the arcjet system with supporting interfaces. Under most circumstances, primary power to the arcjet system was provided by a commercial, phase-control, regulated DC power supply. During conducted transient EMI measurements, eight $12 \mathrm{~V}, 200$ Amp- hr lead-acid batteries connected in series were used as a power source to simulate satellite battery output impedance. At startups, power was switched to the PPU auxiliary, then main inputs by manual activation of electrical relays. Arc ignition and stop command pulses $(+10 \mathrm{~V}, 750$ $\mu s)$ to the PPU were subsequently supplied by a command (CMD) interface pulse generator. Arc current and voltage telemetry (TLM) signals were monitored with a computer data acquisition system. Cabling between the PPU and primary power, CMD, and TLM interfaces consisted of unshielded, twisted pair or bundle pair, approximately $8 \mathrm{~m}$ in length. All negative return leads were grounded to the vacuum tank wall. The arcjet anode was also grounded to the tank wall due to the triax cable configuration and PPU chassis grounding.

\section{Vacuum Facility}

All experimental testing was performed in a $4.6 \mathrm{~m}$ diameter by $19.5 \mathrm{~m}$ long, metal vacuum facility. The pumping system for the chamber included twenty $0.8 \mathrm{~m}$ diameter diffusion pumps followed by blowers and roughing pumps.16 With a propellant mass flow rate of $42.9 \mathrm{mg} / \mathrm{s}$, the facility background pressure was $0.01 \mathrm{~Pa}\left(1 \times 10^{-4}\right.$ torr).

Several small and isolatable test ports were available for access to the main vacuum chamber. A retractable rod assembly supported some of the spacecraft material samples and was inserted via a $0.9 \mathrm{~m}$ port. By retracting the assembly behind an isolation gate valve, the samples were removed and tested for degradation without venting the entire chamber.

Diagnostic Apparatus and Procedure Plume Contamination 


\section{Test Setup}

The arcjet and PPU were mounted to a water-cooled plate in the main portion of the vacuum chamber as shown in Figure 2 . Figure 3 shows the location of stationkeeping arcjets on a simplified schematic of the Series 7000 satellite built by Martin Marietta. Spacecraft samples that were used in the contamination tests included solar cells, optical solar reflectors, thermal blankets, and several paints which are described in more detail in Table $\mathbf{I}$. These samples were positioned to simulate two regions of the satellite. The first region was in the backflow of the arcjet thruster representing surfaces of the main spacecraft body closest to the thruster exit plane. In this region, samples (1-6) were permanently mounted to the PPU thermal interface control plate inside the main vacuum chamber as shown in the schematic of Figure 4 and the photograph in Figure 5. The second region was the solar array panel. In this case, several samples were mounted on a retractable arm assembly which allowed for repeated measurements of sample properties with minimal test interruption. These samples (7-11) were attached to a mounting plate whose normal was pointed directly at the arcjet exit, thus maximizing the incident flow as shown in Figure 4.

\section{Test Procedure}

Due to concerns about contamination of samples by diffusion pump oil, the samples were exposed for 40 hours to the vacuum environment with cold gas flow from an unpowered arcjet. After the control exposure, samples on the retractable arm assembly were moved to an isolatable $0.9 \mathrm{~m}$ diameter port. The gate valve was closed and the port vented to atmosphere. Only the samples on the retractable arm were removed for visual inspection and surface property measurements. The samples were remounted and exposed to the arcjet plume for 40 hours. After this exposure, all samples were removed and their surface properties were tested.

\section{Surface Property Measurements}

The degradation of material performance due to exposure to the arcjet plume was quantified by the measurement of surface properties. Table I describes each of the spacecraft materials and the surface properties measured for each sample.

A spectrophotometer with a $60 \mathrm{~mm}$ diameter barium sulfate coated integrating sphere was used to measure the surface reflectance spectral response. Total solar absorptance over the wavelength range between 250 and $2500 \mathrm{~nm}$ was calculated for an opaque sample by convoluting the reflectance spectra with the solar spectral irradiance according to Equation 1. The accuracy of this measurement was estimated to be within $\pm 2 \%$ and the repeatability of the measurements was \pm 0.005 .17$

$$
\begin{aligned}
& \alpha=1-\rho=1-\left\{\int \rho(\lambda) \mathrm{I}(\lambda) \mathrm{d} \lambda\right\} / \\
& {\left[\int \mathrm{I}(\lambda) \mathrm{d} \lambda\right\}}
\end{aligned}
$$

An infrared reflectometer was used to measure the total room temperature reflectance over the wavelength range between 5 and 25 $\mu \mathrm{m}$. This unit used dual rotating cavities that compared radiation with both a room temperature source and a heated blackbody. Total reflectance, the resultant alternating energy component, was then converted to emittance using Equation 2. The accuracy and the precision of the measurement were 
estimated as $\pm 2 \%$ and \pm 0.005 , respectively.

$$
\varepsilon=1-p
$$

Surface resistance was measured with a high resistance meter. Surface resistance was measured across each sheet of the material from one $7.6 \mathrm{~cm}$ long edge to the opposite edge. In the case of the OSR sample (1), the resistance was measured from the sample surface to the mounting plate. The poor accuracy of the instrument for resistances greater than $1 \times 10^{10}$ ohms, due to electrical noise coupling to the probe cables, was a limitation of this measurement. Therefore, all resistances greater than $1 \times 10^{10}$ ohms were reported by order of magnitude only and an average of three measurements was used as the reported resistance.

Current-voltage curves of the solar cell array were obtained using a filtered xenon arc lamp that simulated the solar spectral irradiance in Earth orbit. A bipolar power supply was used as a power sink by incrementally changing the voltage drop. The cell response was characterized by a voltage measurement across the array and current measurement obtained based on the voltage across a traceable resistor in series with the array. Variation in illumination due to fluctuations in the xenon arc lamp was corrected by using a standard cell. The current of the standard cell was measured simultaneously with the test specimen's current and voltage. The specimen's current was then corrected by the ratio of the calibration current to the measured current of the standard cell. The precision of the voltage measurement was $\pm 0.1 \%$. The illumination variation limited the repeatability of the current measurement to $\pm 1 \%$.
Electrestatic Discharge Characterization

Concerns about the surface property degradation caused by ESD led to the investigation of the discharge phenomenon of charged samples during arcjet ignition. Spacecraft material samples of silicon solar cell array, optical solar reflector, and Si3GLO paint (samples 11, 7, and 10) were individually mounted on a retractable rod assembly which simulated the relative position of the solar array. Each sample was charged by a $20 \mathrm{keV}$ electron beam gun with a $17^{\circ}$ divergence beam that was mounted in a $0.9 \mathrm{~m}$ side port of the test chamber as shown in Figure 4. For these tests the samples were aligned to face the electron beam gun and were mounted to a Kapton coated plate on a movable assembly. A Hall effect current probe measured any induced current in the ground wire that connected the back of the samples to the tank. The output of the current probe was monitored by a digital oscilloscope. The trigger level of the oscilloscope was set at 0.1 A to sense electrostatic discharges, or sparks, which typically result in induced currents of at least 1.0 A.18 Once the oscilloscope was triggered, several parameters, such as time, amplitude, and frequency were recorded and stored by computer. The charging voltage of the samples taken before and after each exposure, were measured by an electrostatic voltmeter and high voltage probe which was attached to another retractable rod assembly as shown in Figure 6.

To determine the impact of charge time on sample charging voltage, electron beam exposure time for the solar cell array was varied from 3 to 18 minutes. 
Exposure times of 3 to 5 minutes were found to maximize the charging voltage without causing excessive sparking. After charging, the samples were moved under the high voltage probe for measurement of the potential with respect to tank ground. Samples were then moved out into the main section of the chamber for exposure to the arcjet plume. After exposure the samples were again moved under the high voltage probe for a second potential measurement.

The charged solar cell array was exposed to the arcjet plume for durations ranging from 1 to 120 seconds, in order to determine the time required to discharge sample potential. The optical solar reflector and S13GLO paint samples were repeatedly charged and exposed to the arcjet plume for 1 second to determine any shot-toshot variations in the observed discharges. Concerns about charge decay over the time necessary for sample movement and surface potential measurement, led to the examination of several operating conditions. Charged samples were placed in the vacuum chamber for 15 minutes to determine the charge decay associated with the movement of the samples on the retractable rod assembly and the exposure to background vacuum. Charged samples were then exposed to the cold gas plume of an unpowered arcjet for 2.25 and 15 minutes to determine if the discharges were caused by neutral species. The 2.25 minute exposure time simulated the conditions of the 1 second powered arcjet exposure, with the exception of thruster ignition, by accounting for time needed to pressurize propellant lines.

Surface degradation of the solar cell array via ESD's was characterized by changes in the current-voltage characteristics. Changes in the OSR and S13GLO samples were quantified by the measurement of the surface properties of absorptance and emittance.

\section{Electromagnetic Interference} Characterization

\section{Equipment and Setup}

Radiated emissions of the arcjet were measured using an array of antennas located a distance of 1 meter from the arcjet exit plane as shown in Figures 5 and 7 . The antennas and their corresponding frequency ranges were: active rod, or monopole, $(10 \mathrm{kHz}$ to $60 \mathrm{MHz}$ ), biconical $(20 \mathrm{MHz}$ to $300 \mathrm{MHz})$, broadband dipole, or BBD, (160 to $500 \mathrm{MHz}$ ), log periodic dipole, or LPD, (1 to $18 \mathrm{GHz}$ ), and hom (26 to $40 \mathrm{GHz})$. Steady state emission spectra were obtained by connecting selected antennas to a $50 \mathrm{kHz}$ to $26.5 \mathrm{GHz}$ superheterodynetype spectrum analyzer. An external mixer allowed extension of the analyzer upper frequency limit to $40 \mathrm{GHz}$ when used with the horn antenna. Arc ignition radiated transients were captured by connecting the biconical or $B B D$ antennas to the $50 \mathrm{ohm}$ input of a $500 \mathrm{MHz}$ bandwidth digital storage oscilloscope. Antenna cables were of the coaxial type $\mathrm{RG} 58 \mathrm{C} / \mathrm{U}$ for the active rod, biconical, and $B B D$ antennas. RG214/U was used with the LPD and RG223/U with the external mixer of the horn antenna. A short segment of flexible waveguide connected the hom antenna to the external mixer. Conducted voltage transients were monitored with a matched pair of passive, $\times 10$ attenuation voltage probes using a digital storage oscilloscope (DSO). These gave an effective measurement bandwidth of $\mathrm{DC}$ to $200 \mathrm{MHz}$. Differential measurements were obtained by waveform subtraction. 
Procedure

Table II shows the frequency bands for which steady state radiated emission measurements were taken. Spectrum analyzer sweeps of each band were acquired using positive peak detection with the (predetection) resolution bandwidths indicated. These measurements were performed for both arcjet/PPU off and on conditions to allow discrimination of background or ambient signals from arcjet/PPU generated emissions. Data were saved by hardcopy plots of the analyzer display. These were later digitized so that frequency dependent conversion factors could be applied to obtain narrowband and broadband field strengths at the antennas.

Prior to capturing the transient radiated emissions produced at arc ignition the arcjet was cycled while reducing the DSO trigger level until reliable triggering was obtained on arc start. A similar procedure was used for acquisition of conducted emission transients during the three arcjet/PPU startup stages of auxiliary power application, main power application, and arc start. These conducted transients were measured with short time scale (2 to $5 \mu s)$, maximum bandwidth DSO sweeps. Longer time scale (20 ms) sweeps were also used to discriminate relay closure and bounce spikes from the power surge transients of interest. Voltage probe compensation was periodically checked with the DSO square wave calibration source to assure accurate transient representation.

Results and Discussion

Plume Contamination
Surface properties of samples $7-11$, mounted in the simulated solar array region, taken before and after exposure to the cold gas from an unpowered arcjet are listed in Tables III(a) and III(b). The difference between initial and final properties was defined to be within experimental error when the difference was less than twice the uncertainty. This definition accounts for overlap of measurement error bars between both measurements. In the case of absorptance and emittance, a measureable change occurred when the difference was greater than 0.01. With the exception of the absorptance of Z93, sample 9, the changes in absorptance and emittance of all samples were within the experimental accuracy of the measurements. The measurable change in the absorptance of $\mathrm{Z93}$ might have been due to a coating of backstreaming diffusion pump oil. Minor variation in the surface resistance was measured for both samples 8 and 9 . These variations were small relative to the uncertainty of the measurement.

The solar cell array currentvoltage curves taken before and after exposure to the cold gas arcjet plume are shown in Figure 8(a). Changes in the solar cell array (sample 11) current-voltage characteristics are listed in Table III(b). Comparison of the initial and final values of short circuit current and open circuit voltage showed changes of less than $0.5 \%$ and $0.05 \%$, respectively. Both were within experimental error. Other parameters included in Table III(b) are defined as follows in Equations 3 and 4:

$$
\begin{aligned}
& \mathrm{FF}=\mathrm{P}_{\max } /\left(\mathrm{I}_{\mathrm{sc}} \mathrm{V}_{\text {oc }}\right) \\
& \eta=\mathrm{P}_{\max } / \mathrm{P}_{\text {input }}=\mathrm{P}_{\max } /\left(\mathrm{C}_{\mathrm{s}}\right. \\
& \text { A) }
\end{aligned}
$$


The changes in the derived parameters of maximum power, fill factor, and efficiency were all less than $0.6 \%$, which was within experimental error.

The surface properties of the samples, measured before and after exposure to a powered arcjet plume, are listed in Tables IV(a) and IV(b). Absorptance decreased in both cases where the change was greater than experimental error. For sample 1 it was not clear whether the difference was due to differences in measurement techniques or some effect attributable to the arcjet. The change in absorptance for sample 9 led to possible conclusions that either the arcjet evaporated pump oil contamination on the Z93 or the post-control absorptance was measured on a different portion of the sample resulting in a false degradation. The change in emittance was greater than experimental error in only one case, where the emittance of the thermal blanket (sample 4) decreased significantly. Again, it was not certain whether this change was due to arcjet exposure or a discrepancy in measurement techniques.

The resistance of one $\mathrm{Z93}$ paint sample (5) decreased significantly during the exposure to the arcjet. However, decreasing surface resistance would tend to lower differential charging through an increase of charge leakage to spacecraft ground. The resistance increased for only one of the OSR samples (1) and one of the Z93 white paint samples (9). An estimate of the end of life resistance was calculated using a linear extrapolation based on the change in resistance after 40 hours. The ratio of the test exposure time to the total thruster operation time on the satellite gave the extrapolation factor of 16.25. The final resistances after 650 hours of exposure to the arcjet for the OSR and $Z 93$ samples were calculated to be $4.8 \times 10^{8} \mathrm{ohms}$ and $3.7 \times 10^{8}$ ohms, respectively. Both extrapolated resistances were lower than the maximum of $1 \times 10^{9}$ ohms, typically specified for spacecraft. 11

Table IV(b) lists the important characteristics of the solar cell current-voltage curves shown in Figure $8(\mathrm{~b})$. The first measurement of the currentvoltage curve measured a decrease of $56 \mathrm{mV}$ in the open circuit voltage, but only a $4 \mathrm{~mA}$ increase in the short circuit current. An increase in the cell operation temperature is known to cause a slight increase in the cell current, at a rate of $0.03 \% /^{\circ} \mathrm{C}$, and a significant decrease in the voltage, at a rate of 2.2 to $2.3 \mathrm{mV} /{ }^{\circ} \mathrm{C} .19$ An increase in the operating temperature of 3 to $6^{\circ} \mathrm{C}$ would have accounted for the differences previously noted for a 4 by 4 solar cell array. The measurement was repeated the next day under controlled thermal conditions. The results are listed in Table IV(b) and plotted in Figure 8(b). Both open circuit voltage and short circuit current repeated the original measurements within experimental error. This information suggested that variation of the measurement procedure caused the solar cell array to be heated by the xenon arc lamp which probably caused the non-repeatable change in currentvoltage characteristics.20 The changes in the derived parameters of maximum power, fill factor, and efficiency were all less than $0.6 \%$, based on the final current-voltage trace, which was within experimental error.

Electrostatic Discharge Characterization 
Sample charging times were varied from 3 to 18 minutes in order to determine the maximum attainable charging voltage for each sample. It was found that each sample quickly reached a potential beyond its breakdown threshold and an arc would form causing a decrease in the charging voltage. As a result of spark discharges, the oscilloscope was always triggered and sample potentials never reached ground potential. In one case the solar cell array potential increased from -8900 to -5800 volts when the sample sparked to the high voltage probe as it was being retracted. After the initial discharge event, a cyclic pattern of discharges occurred on a fairly regular interval as long as the electron beam charging process continued. Maximum potential difference or charging voltage was obtained, typically after 3 to 5 minutes, by turning off the electron beam gun before the next anticipated spark. The maximum charging voltage varied for each sample and depended on surface resistance. The maximum charging voltages for the solar cell array, OSR, and S13GLO samples were -9700 , $-11,600$, and -300 volts, respectively. Examinations of several control conditions were done with the solar cell array due to concerns about charge decay caused by movement of the samples with the retractable rod assembly, the time delay in the voltage measurement, and exposure of samples to the cold gas arcjet. The solar cells were charged to -5100 volts and inserted into the test chamber. After a 15 minute exposure to vacuum, the sample potential was -4600 volts. Since the oscilloscope was not triggered during this period, some charge dissipation mechanism, perhaps a low-current Townsend discharge or charge leakage to the support, caused some decay in the negative potential. Charge decay due to the exposure of the solar cell array to the cold gas arcjet for $\mathbf{2 . 2 5}$ minutes was also investigated. It was found that the potential changed from an initial -7900 volts to -7000 volts. Like the vacuum exposure, a reduction in the potential occurred, but the sample was still negatively biased to tank ground. Finally, all three samples were exposed for 2.25 minutes to a cold gas arcjet with the PPU auxiliary power on. All samples experienced changes in voltage potential without sparks during the exposure, but none reached ground potential during the exposure.

The solar cell array was exposed to the powered arcjet for exposure times of $1,6,60$, and 120 seconds. During every exposure the initial negative potential, which ranged from -8100 to -7000 volts, was raised to ground potential $(0 \pm 2$ volts) without triggering the oscilloscope. It was believed that sparking was not the discharge mechanism, because the oscilloscope was not triggered in the process and charging voltage was raised to zero. The OSR and S13GLO samples were charged 5 and 2 times, respectively, and exposed for 1 second to the arcjet without triggering the oscilloscope. The charging voltages ranged from 11,600 to -5800 volts for the optical solar reflector, while the preexposure potentials were -300 and 200 volts for the S13GLO paint sample. The potentials of all charged samples were benignly and consistently raised to ground potential without triggering the oscilloscope during arcjet exposure.

The changes of the optical properties of absorptance and emittance for the OSR and paint samples resulting from the ESD tests are listed in Table $V(a)$. All changes in the surface properties were within experimental error of the instrumentation. This result was not completely unexpected based on 
the limited number of charging cycles for each sample. However, it should be stated that any optical degradation due to ESD damage would not be induced by the ignition of the arcjet thruster. Current-voltage characteristics for the solar array measured before and after the electrostatic discharge testing showed little variation. Table $V(b)$ lists the before and after exposure current-voltage characteristics for the solar array. Traces are shown in Figure $8(\mathrm{c})$. All measured final properties repeated original measurements within experimental error.

Electromagnetic Interference Characterization

Nearly the complete set of EMI data is included within Figures 9-19. The discussion below concentrates on the prominent features of the data and, where possible, their comparison with other work.9

Steady state radiated emission signals and/or thresholds recorded with the spectrum analyzer were corrected to give corresponding narrowband and broadband field strengths at the antennas. Details of this data reduction are discussed in the Appendix.

Figures 9(a) shows the results for narrowband emissions at ambient conditions, while Figures 9(b) and 9(c) show narrowband emissions during arcjet operation using PPU's $A$ and $B$, respectively. Discontinuities which appear in the various plots were due to analyzer bandwidth and attenuation changes as outlined in Table II. Comparison of the two PPU cases against the ambient plot demonstrated the radiated emissions attributable to operation of the arcjet system. The narrowband spikes apparent from $50 \mathrm{kHz}$ to $1 \mathrm{MHz}$ in Figures $9(\mathrm{~b})$ and 9(c) were separated by the corresponding PPU switching frequencies, about $16 \mathrm{kHz}$ for PPU A and about $20 \mathrm{kHz}$ for PPU B. These "switching harmonics" continued out to around $20 \mathrm{MHz}$ but were unresolved by the larger $30 \mathrm{kHz}$ resolution bandwidth used above 1 $\mathrm{MHz}$. In both PPU cases the narrowband spikes associated with PPU switching exceeded the MILSTD-461C limit by up to $20 \mathrm{~dB}$ for frequencies below 1 to $2 \mathrm{MHz}$. When compared to previous results, 9 in which the same arcjet and PPU were used, the levels of this test appeared to be about 20 to $40 \mathrm{~dB}$ lower. However, as discussed in the broadband analysis below, the signal levels for both narrowband and broadband emissions measured in this test with the active rod antenna $(50 \mathrm{kHz}$ to 50 $\mathrm{MHz}$ ) were likely being underdisplayed, or compressed, due to saturation of the antenna amplifier by a high level of arcjet associated low frequency broadband noise. This also accounted for suppression of ambient signals between 1 and $50 \mathrm{MHz}$ in both PPU cases, which is apparent when comparison is made to Figure $9(a)$. As a result of the active rod saturation, quantitative emission level comparisons between arcjet operation for PPU's $A$ and $B$ were not considered appropriate. Nevertheless, in qualitative terms, it may be said that the spectral signatures were similar and in both cases exceeded the MIL-STD-461C limit by at least 5 to $20 \mathrm{~dB}$ for frequencies less than $2 \mathrm{MHz}$.

Two other points concerning the narrowband emission plots should be noted. First, the reduced level in the 10 to $50 \mathrm{MHz}$ range of the PPU B plot compared to the ambient or PPU A plots was a result of a $10 \mathrm{~dB}$ difference in analyzer input attenuation and, therefore, noise measurement threshold. Secondly, the elevated narrowband spike at $455.6 \mathrm{MHz}$ in Figures 9(b) 
and 9 (c) relative to the ambient level in Figure 9(a) should not be attributed to the arcjet or the PPU, as the magnitudes of such ambient emissions were often found to vary from measurement to measurement. Figures $10(\mathrm{a})$ - $10(\mathrm{c})$ show the broadband emission results for conditions similar to those of the narrowband plots in Figures 9(a) 9(c). As indicated in Table II, however, larger resolution bandwidths were used in some instances to achieve better sensitivity, or lower threshold, to coherent broadband emissions. The most striking feature evident when comparing Figures 10(a) - 10(c) is the increased level of low frequency broadband noise during arcjet operation. This emission exceeded the MIL-STD-461C specification for frequencies up to $300 \mathrm{kHz}$. However, it also exceeded the active rod antenna saturation limit of $+105 \mathrm{~dB} \mu \mathrm{V} / \mathrm{m} / \mathrm{MHz}$. Although it appeared that this saturation occurred only for frequencies less than or equal to $150 \mathrm{kHz}$, the actual effect was a compression of signal level across the entire $50 \mathrm{kHz}$ to $50 \mathrm{MHz}$ active rod band, as mentioned earlier. Avoidance of this problem would have required use of an active rod with pre-gain stage attenuation or a passive rod antenna. Due to time constraints, neither was available during testing.

A slight difference in noise threshold between Figures 10(a) and $10(\mathrm{c})$ for the 10 to $50 \mathrm{MHz}$ range was due to a $10 \mathrm{~dB}$ change in attenuation and use of a smaller resolution bandwidth in the PPU B case. Likewise, the lower threshold for 10 to $50 \mathrm{MHz}$ in Figure $10(\mathrm{~b})$ compared to $10(a)$ or $10(\mathrm{c})$ was the result of switchout of analyzer attenuation. Emission peaks at 11.6 $\mathrm{MHz}$ and $15.7 \mathrm{MHz}$ in Figure $10(\mathrm{c})$ were examined closely and found to be $95 \mathrm{kHz}$ harmonics and $1.3 \mathrm{~Hz}$ impulses, respectively. These were believed to have been intermittent ambient signals. Though not present in Figure 10(a), the peak between 212 to $215 \mathrm{MHz}$ in Figure 10 (b) was also found to be a temporary ambient signal.

Overall, comparison of the broadband results in Figures $10(\mathrm{~b})$ and $10(\mathrm{c})$ with previous work,9 revealed a general similarity in spectral profile. In both tests, a high level of broadband noise exceeding MIL-STD-461C was apparent for low frequencies. This noise rolled off by 20 to $30 \mathrm{~dB}$ per decade with increasing frequency. Since the communication bands of interest are well above this frequency range, no radiated EMI problems are foreseen for steady state arcjet operation on a commercial communications satellite.

To verify that arcjet radiated emissions were not a problem at critical satellite communication frequencies, a set of sweeps was conducted which focused on selected communications bands. The results for UHF, S, C, Ku, and $\mathrm{Ka}$ bands are displayed in Figures 11. 15, respectively. No ambient or arcjet related emissions were found for any of these frequency ranges to the sensitivity levels indicated in the figures. Improved sensitivity, that is, lower noise measurement thresholds were desired, but required impractically long sweep times (using smaller resolution bandwidths) for the narrowband case and/or use of more sensitive measurement equipment in the broadband case. Nevertheless, it was clear from Figures 11-13 that arcjet narrowband emission levels in the UHF, $S$, and $C$ bands were below the MIL-STD-461C narrowband specifications. Since this narrowband limit terminates at $10 \mathrm{GHz}$, it does not appear in the $\mathrm{K}$ band plots of Figures 14 and 15 . Arcjet broadband emissions in the UHF band investigated may also be 
concluded to be within the MILSTD-461C broadband limits as Figure 11 shows. Because this specification extends only to $1 \mathrm{GHz}$, it is not shown in Figures 12-15. It is also noteworthy that measurement sensitivity tends to become poorer at higher frequencies as the "step" feature around $6.2 \mathrm{GHz}$ in Figure 13 highlights. This discontinuity in sensitivity level reflects a change in the spectrum analyzer local oscillator harmonic and corresponding increase in analyzer internal noise.

Arc ignition radiated transients were observed using the biconical and broadband dipole antennas. Figures 16 and 17 show the resulting triggered time domain signals received from these antennas during arcjet ignition. Although not unfolded from antenna factors, these waveforms give some indication of how long transient high frequency components may take to reach steady state levels. From Figures 16(a) and 17(a), it would appear this occurred within 1 to $2 \mu \mathrm{s}$ for the 20 to $500 \mathrm{MHz}$ antenna band. However, effects of test chamber reverberation and antenna cable internal reflections or ringing were difficult to distinguish when analyzing such transients. These factors would, however, prolong the decay of the observed transient relative to that which actually would occur in an open environment as in space. Figures 16(b) and 17(b), which are expanded segments of 16(a) and 17(a), show risetimes of 15 to $40 \mathrm{~ns}$ and dominant oscillations of 50 to $200 \mathrm{MHz}$. To obtain a better picture of the spectral content and radiated emission field levels represented by the time domain pulses, the trace of Figure 16(b) was numerically Fourier analyzed. Antenna factors were then applied to yield Figure 18 which shows the transient broadband radiated emission levels over the 20 to $300 \mathrm{MHz}$ biconical antenna band. The large dips in the spectrum are an artifact of the truncation of the pulse in Figure 16(b) at approximately 160 ns. For reference, an error in amplitude of two percent makes the digitization noise floor in Figure 18 about $34 \mathrm{~dB}$ below peak, or about 32 $\mathrm{dB} \mu \mathrm{V} / \mathrm{m} / \mathrm{MHz}$. At $60 \mathrm{MHz}$ the spectrum shows a peak emission of $66 \mathrm{~dB} \mu \mathrm{V} / \mathrm{m} / \mathrm{MHz}$ which was still within the steady state MIL-STD461C broadband limit. The high frequency rolloff in emission level of approximately 7 to $10 \mathrm{~dB} /$ decade appears to maintain compliance with the steady state MIL-STD-461C limit for frequencies above $60 \mathrm{MHz}$. However, the transient emission levels appear significant (measurable) to at least $300 \mathrm{MHz}$ and thereby warrant more extensive investigation.

Voltage transients observed on the primary power, command "ON", and arc current telemetry lines at the stages of PPU/arcjet startup are outlined in Table VI. Included for comparison are the transient levels or amplitudes from PPU B switching, captured during steady state arcjet operation. Figure 19 shows an example of a transient on the primary power lines at the moment of battery power application to the main power input of PPU B. The MIL-STD-461C CEO7 specification calls for such dc power line transients to not exceed $+50 \%$ or $-150 \%$ of the nominal line voltage. For the $+96 \mathrm{~V}$ primary power voltage here, this corresponds to upper and lower limits of $+144 \mathrm{~V}$ and $-48 \mathrm{~V}$. As can be seen for the example of Figure 19 and from the values of Table VI, the auxiliary on, main on and arc start events result in power line transients which are within the appropriate limits except for a minor $+7 \mathrm{~V}$ violation of the upper limit in the main on case. The MILSTD-461C CEO7 specification does not 
apply to the command and telemetry signal lines which do not have fixed line voltages, but 0 to $5 \mathrm{~V}$ ranges. Transient peak to peak amplitudes were nevertheless recorded and durations found to be less than $2 \mu \mathrm{s}$. Effects of CMD/TLM interface impedance characteristics on the CMD/TLM lines were not investigated here. In prior integration testing, 9 no changes in telemetry data were observed during arcjet ignition.

\section{Conclusions}

In order to address residual user integration concerns in the application of hydrazine arcjets on commercial communications satellites, an integration test was performed under a Space Act agreement between Martin Marietta Astro Space, the Rocket Research Company, and NASA Lewis Research Center. In this test, plume contamination on spacecraft material samples, electrostatic discharge phenomena, and electromagnetic compatibility were investigated.

Potential contamination of spacecraft surfaces was investigated by positioning spacecraft material samples relative to the arcjet thruster in order to simulate both the satellite body and solar array regions of a typical communications satellite. Contamination was quantified by the measurement of surface properties both before and after the exposure. The samples in the simulated solar array region were exposed to the cold gas arcjet plume for 40 hours to address concerns about contamination by backstreaming diffusion pump oil. With the exception of one sample, no significant changes were measured in absorptance and emittance within experimental error. Surface property measurements taken before and after the exposure to a powered arcjet plume revealed several things. Absorptance decreased in two cases where only minor changes were measurable. The decrease in emittance of a thermal blanket sample was the only measurable degradation of this experiment. Measurable changes in resistance yielded acceptable end of life characteristics. The contamination of a silicon solar cell array was quantified by the measurement of the currentvoltage characteristics both before and after exposure to the cold gas arcjet and powered arcjet plume. No measurable change in the current-voltage characteristics occurred with the exception of a non-repeatable shift in one measurement believed to be a temperature effect and not a contamination issue.

Concerns about the surface property degradation caused by electrostatic discharges led to the investigation of the discharge phenomenon of charged samples during arcjet ignition. Short duration exposures of charged samples demonstrated that the potential differences were consistently and completely eliminated within the first second of exposure to the weakly ionized plume. The spark discharge mechanism was not the discharge phenomenon since the charging voltage was completely dissipated and the discharge process did not trigger the oscilloscope with a signal from the current probe, which measured the induced current in the sample ground strap. In contrast, spark discharges were found to trigger the current probe, but not completely dissipate charging voltages. Exposure to control conditions did not cause a significant dissipation in charging voltage. These results suggest that 
the arcjet could act as a charge control device on spacecraft.

Steady state radiated narrowband and broadband emissions were measured for various frequency ranges between $50 \mathrm{kHz}$ to $40 \mathrm{GHz}$. Comparison of results for arcjet operation on two different power processing units showed similar spectral characteristics for both narrowband and broadband emissions. Broadband emissions exceed the MIL-STD-461C below 0.3 MHz while previous work has shown that the upper frequency of excessive emissions extended to 40 MHz. The difference between results may be explained by saturation of the active monopole antenna. Sweeps of special UHF, S, $\mathrm{C}, \mathrm{Ku}$, and $\mathrm{Ka}$ bands showed no narrowband or broadband emissions above the measurement thresholds, which were below the MIL-STD-461C standards.

\section{Acknowledgements}

This project has been cosponsored by Martin Marietta Astro Space Independent Research and Development and NASA LeRC. The authors would like to thank Rocket Research Company and Pacific Electro Dynamics for providing the PED engineering development model PPU and the invaluable expertise of Peter Skelly. The authors would also like to thank James Armenti for his technical assistance, particularly in the assembly and operation of the electrostatic discharge test equipment. The authors would like to recognize the insightful advice of Charles Bowman in association with these activities. Finally, the authors would like to acknowledge the dedicated support provided by the Test Installations Division of the Electric Power Laboratory.

\section{References}

1. Curran, F. M. and Haag, T. W., "An Extended Life and Performance Test of a Low Power Arcjet," AIAA 883106, July 1988, (NASA TM 100942).

2. Gruber, R. P., "Power Electronics for a 1-Kilowatt Arcjet Thruster," AIAA 86-1507, June 1986, (NASA TM 87340).

3. Knowles, S. K., "Arcjet Thruster Research and Technology, Phase II," NASA CR-182276, Rocket Research Co., Redmond, WA, March 1991.

4. Carney, L. M. and Keith, T. G., "Langmuir Probe Measurements of an Arcjet Exhaust," Journal of Propulsion and Power, Vol. 5, No. 3, May-June 1989, pp 287-294.

5. Carney, L. M. and Sankovic, J. M., "The Effects of Arcjet Operating Condition and Constrictor Geometry on the Plasma Plume," AIAA 892723, July 1989, (NASA TM 102284).

6. Sankovic, J. M., "Investigation of the Arcjet Plume Near Field Using Electrostatic Probes," NASA TM 103638, October 1990.

7. Carney, L. M., "Evaluation of the Communication Impact of a Low Power Arcjet Thruster," AIAA 883105, July 1988, (NASA TM 100926).

8. Ling, H. et al., "Effect of Arcjet Plume on Satellite Reflector Performance," IEEE Transactions on Antennas and Propogation, Vol. 39, No. 9, September 1991, pp 1412-1420.

9. Zafran, S., "Hydrazine Arcjet Propulsion Integration Testing," IEPC 91-013, Proceedings of the 22 nd International Electric Propulsion Conference, October 1991. 
10. Bogorad, A., et al." The Effects of Arcjet Plasma Propulsion Systems on Spacecraft Charging and Spacecraft Thermal Control Materials," IEEE Transactions on Nuclear Science, Vol. 39, No. 6, pp 1783-1789, December 1992.

11. Purvis, C.K., et al., "Design Guidelines for Assessing and Controlling Spacecraft Charging Effects," NASA TP 2361, 1984.

12. Bogorad, A., et al., "Electrostatic Discharge Induced Thermo-Optical Degradation of Optical Solar Reflectors (OSRs)," IEEE Transactions on Nuclear Science, Vol. 38, No. 6, pp 1608-1613, December 1991.

13. Bogorad, A., et al., "Relation Between Electrostacic Discharge Rate and Outgassing Rate," IEEE Transactions on Nuclear Science, Vol. 36, No. 6, pp 2021-2026, December 1989.

14. Morren, W. E. and Lichon, P. J.,"Low-Power Arcjet Test Facility Impacts," AIAA 92-3532, July 1992.

15. Skelly, P. T., Fisher, J. R., and Golden, C. M., "Power Conditioning Unit for Low-Power Arcjet Flight Application," Pacific Electro Dynamics, Redmond, WA, AIAA 923529, July 1992.

16. Sovey, J., et al., "Test Facilities for High Power Electric Propulsion," AIAA 91-3499, September 1991, (NASA TM 105247).

17. Dever, J. A., et al., "Evaluation of Thermal Control Coatings for Use on Solar Dynamic Radiators in Low Earth Orbit," AIAA 91-1327, June 1991, (NASA TM 104335).

18. Bogorad, A., et al., "Amplitude Scaling of Solar Array Discharges," IEEE Transactions on Nuclear
Science, Vol. 37, No. 6, pp 2112-2119, December 1990.

19. Agrawal, B.N., Design of Geosynchronous Spacecraft, Prentice-Hall Inc., Englewood Cliffs, NJ, 1986.

20. Brinker, D.J.: Private communication.

21. Engelson, M. and Telewski, F., Spectrum Analyzer Theory and Applications, Artech House, Dedham, MA, 1979.

\section{Appendix}

Data displayed by the spectrum analyzer reflected a signal (noise) level, whether internal to the analyzer or external from an antenna, which was referenced to the spectrum analyzer input. This level was expressed in logarithmic terms as the equivalent rms voltage to a power dissipated in its $50 \mathrm{ohm}$ input impedance. That is, signal was shown in decibels relative to $1 \mu \mathrm{V}$, or $\mathrm{dB} \mu \mathrm{V}$ where

$$
\Phi(\mathrm{dB} \mu \mathrm{V})=20 \log [\Phi(\mu \mathrm{V}) / 1 \mu \mathrm{V}]
$$

Spectra were recorded by plotting out the spectrum analyzer display. These plots were later digitized so that frequency dependent corrections such as antenna factor and cable loss could be applied to yield corresponding electric field strengths at the antennas. For the narrowband type analysis the following equation was used on all data:

$$
\begin{aligned}
& \mathrm{NB}(\mathrm{dB} \mu \mathrm{V} / \mathrm{m})=\Phi(\mathrm{dB} \mu \mathrm{V})+ \\
& \mathrm{AF}(\mathrm{dB} / \mathrm{m})+\mathrm{CL}(\mathrm{dB})
\end{aligned}
$$

Conversion loss of the external mixer for the horn antenna is not included in Equation 6 because it 
was accounted for by the spectrum analyzer. The antenna factor and cable loss factor were obtained from manufacturer supplied ANSI C63.5 antenna calibrations and calculated cable attenuations, respectively.

Broadband type noise analysis was accomplished by first selectively deleting clearly identified narrowband type signals from the tabulated data generated with Equation 6 . Because broadband noise levels may depend on the receiver bandwidth used, an additional bandwidth normalization factor was then applied to yield broadband emission levels as:

$$
\begin{aligned}
& B B(d B \mu V / m / M H z)= \\
& N B(d B \mu V / m)+B N F(d B)
\end{aligned}
$$

This corrected noise levels from those observed with the spectrum analyzer 3 dB Gaussian resolution bandwidth to those observed with a standard $1 \mathrm{MHz}$ impulse bandwidth. The correction assumed (worst case) coherent type noise - i.e. noise for which a $\times 10$ change in bandwidth results in a $20 \mathrm{~dB}$ change in noise level. Since the equivalent impulse bandwidth of a Gaussian shaped filter is approximately 1.5 times the Gaussian $3 \mathrm{~dB}$ bandwidth,2 I the normalization factor was given by:

$$
\begin{aligned}
& \mathrm{BNF}(\mathrm{dB})=20 \log \{(1 \\
& \mathrm{MHz}) /[1.5 \mathrm{RB}(\mathrm{MHz})]\}
\end{aligned}
$$

\begin{tabular}{|c|c|c|c|c|}
\hline $\begin{array}{l}\text { Sample } \\
\text { Number }\end{array}$ & Description & $\begin{array}{l}\text { Simulated } \\
\text { Location on } \\
\text { Spacecraft }\end{array}$ & $\begin{array}{c}\text { Size } \\
(\mathrm{cm} \times \mathrm{cm})\end{array}$ & $\begin{array}{l}\text { Properties } \\
\text { Evaluated }\end{array}$ \\
\hline 1 & $\begin{array}{c}\text { Four Indium-tin oxide (ITO) } \\
\text { coated CMX OSR's on an } \\
\text { aluminum plate } \\
\end{array}$ & Backflow & $7.6 \times 7.6$ & $\alpha, \varepsilon, R$ \\
\hline 2 & $\begin{array}{l}\text { S13GLO white paint on } \\
\text { aluminum }\end{array}$ & Backflow & $7.6 \times 12.7$ & $\alpha, \varepsilon, R$ \\
\hline 3 & $\begin{array}{l}\text { MH21SLO black paint on } \\
\text { aluminum }\end{array}$ & Backflow & $7.6 \times 12.7$ & $\alpha, \varepsilon, R$ \\
\hline 4 & $\begin{array}{l}0.13 \mathrm{~mm} \text { Dupont Kapton }, \\
\text { second-surface-aluminized } \\
\text { thermal blanket material }\end{array}$ & Backflow & $15.2 \times 15.2$ & $\overline{\alpha, \varepsilon}$ \\
\hline 5 & Z93 white paint on aluminum & Backflow & $7.6 \times 12.7$ & $\alpha, \varepsilon, R$ \\
\hline 6 & Z306 black paint on aluminum & Backflow & $7.6 \times 12.7$ & $\alpha, \varepsilon$ \\
\hline 7 & $\begin{array}{l}\text { Six fused silica Optical Solar } \\
\text { Reflectors on a } 1.3 \mathrm{~cm} \\
\text { honeycomb panel }\end{array}$ & Solar Array & $7.6 \times 12.7$ & $\alpha, \varepsilon$ \\
\hline 8 & Carbon-loaded Kevlar & Solar Array & $7.6 \times 12.7$ & $\alpha, \varepsilon, \mathbf{R}$ \\
\hline 9 & 293 white paint on aluminum & Solar Array & $7.6 \times 12.7$ & $\alpha, \varepsilon, \mathrm{R}$ \\
\hline 10 & $\begin{array}{c}\text { S13GLO white paint on } \\
\text { aluminum }\end{array}$ & Solar Array & $7.6 \times 12.7$ & $\alpha, \varepsilon, R$ \\
\hline 11 & $\begin{array}{l}\text { A four element by four element } \\
\text { silicon solar cell array circuit } \\
\text { on a Dupont Kevlar } ₫ \text { skin } \\
\text { honeycomb panel with fused } \\
\text { silica coverglasses }\end{array}$ & Solar Array & $10.2 \times 12.7$ & $\begin{array}{l}\text { Current- } \\
\text { voltage trace }\end{array}$ \\
\hline
\end{tabular}

Table I - Spacecraft materials description and placement. 
Table II - Antenna types and spectrum analyzer bandwidths for the frequency ranges investigated during steady state conditions.

\begin{tabular}{|c|c|c|c|c|c|c|c|c|}
\hline \multirow[b]{3}{*}{ Antenna } & \multirow[b]{3}{*}{ Band } & \multirow[b]{3}{*}{$\begin{array}{l}\text { Frequency } \\
\text { Range }(\mathrm{Hz})\end{array}$} & \multicolumn{6}{|c|}{ Resolution Bandwidths* $(\mathrm{Hz})$} \\
\hline & & & \multicolumn{3}{|c|}{ Narrowband } & \multicolumn{3}{|c|}{ Broadband } \\
\hline & & & Ambient & PPU A & PPU B & Ambient & PPU A & PPU B \\
\hline $\begin{array}{c}\text { Active } \\
\text { Rod } \\
\text { Monopole }\end{array}$ & $\begin{array}{l}\text { Broad } \\
\text { Range }\end{array}$ & $50-250 \mathrm{k}$ & 100 & 100 & 100 & 100 & 100 & 100 \\
\hline $\begin{array}{c}\text { Active } \\
\text { Rod } \\
\text { Monopole }\end{array}$ & $\begin{array}{l}\text { Broad } \\
\text { Range }\end{array}$ & $250 \mathrm{k}-1 \mathrm{M}$ & 300 & 300 & 300 & 300 & 300 & 300 \\
\hline $\begin{array}{c}\text { Active } \\
\text { Rod } \\
\text { Monopole }\end{array}$ & $\begin{array}{l}\text { Broad } \\
\text { Range }\end{array}$ & $1-10 \mathrm{M}$ & $30 \mathrm{k}$ & $30 \mathrm{k}$ & $30 \mathrm{k}$ & $30 \mathrm{k}$ & $30 \mathrm{k}$ & $30 \mathrm{k}$ \\
\hline $\begin{array}{c}\text { Active } \\
\text { Rod } \\
\text { Monopole }\end{array}$ & $\begin{array}{l}\text { Broad } \\
\text { Range }\end{array}$ & $10-50 \mathrm{M}$ & $10 \mathrm{k} * *$ & $10 \mathrm{k} * *$ & $10 \mathrm{k}$ & $300 \mathrm{k} * *$ & $300 \mathrm{k}$ & $10 \mathrm{k}$ \\
\hline BBD & $\begin{array}{l}\text { Broad } \\
\text { Range }\end{array}$ & $160-500 \mathrm{M}$ & $10 \mathrm{k}$ & $10 \mathrm{k}$ & $10 \mathrm{k}$ & $300 \mathrm{k}$ & $300 \mathrm{k}$ & $300 \mathrm{k}$ \\
\hline BBD & UHF & $240-255 \mathrm{M}$ & $10 \mathrm{k}$ & - & $10 \mathrm{k}$ & $300 \mathrm{k}$ & - & $300 \mathrm{k}$ \\
\hline LPD & $\mathbf{S}$ & $2.6-2.7 \mathrm{G}$ & $10 \mathrm{k}$ & - & $10 \mathrm{k}$ & $300 \mathrm{k}$ & - & $300 \mathrm{k}$ \\
\hline LPD & C & $5.9-6.4 \mathrm{G}$ & $10 \mathrm{k}$ & - & $10 \mathrm{k}$ & $300 \mathrm{k}$ & - & $300 k$ \\
\hline LPD & $\mathbf{K u}$ & $14.0-14.5 \mathrm{G}$ & $10 \mathrm{k}$ & - & $10 \mathrm{k}$ & $300 k$ & - & $300 k$ \\
\hline Horn & $\mathbf{K a}$ & $27.5 .30 \mathrm{G}$ & $10 k$ & - & $10 k$ & $300 \mathrm{k}$ & - & $300 k$ \\
\hline
\end{tabular}

* Video (post-detection) bandwidths $\geq$ resolution bandwidths for peak detection.

** Analyzer input attenuation $=10 \mathrm{~dB}$.

Table III - Initial and final property measurements for $\mathbf{4 0}$ hour exposure to control conditions.

Table III(a) - Initial and final surface properties of samples exposed for 40 hours to the cold gas from an unpowered arcjet.

\begin{tabular}{|c|c|c|c|c|c|c|}
\hline $\begin{array}{c}\text { Sample } \\
\text { Number }\end{array}$ & $\begin{array}{c}\text { Initial } \\
\text { Absorptance } \\
( \pm 0.005)\end{array}$ & $\begin{array}{c}\text { Final } \\
\text { Absorptance } \\
( \pm 0.005)\end{array}$ & $\begin{array}{c}\text { Initial } \\
\text { Emittance } \\
( \pm 0.005)\end{array}$ & $\begin{array}{c}\text { Final } \\
\text { Emittance } \\
( \pm 0.005)\end{array}$ & $\begin{array}{c}\text { Initial } \\
\text { Resistance } \\
\text { (ohms) }\end{array}$ & $\begin{array}{c}\text { Final } \\
\text { Resistance } \\
\text { (ohms) }\end{array}$ \\
\hline 7 & 0.038 & 0.042 & 0.804 & 0.802 & - & - \\
\hline 8 & 0.939 & 0.940 & 0.894 & 0.892 & $0.9 \times 10^{7}$ & $1.2 \times 10^{7}$ \\
\hline 9 & 0.127 & 0.138 & 0.918 & 0.915 & $2.8 \times 10^{7}$ & $2.4 \times 10^{7}$ \\
\hline 10 & 0.198 & 0.201 & 0.901 & 0.899 & - & - \\
\hline
\end{tabular}


Table III - Initial and final property measurements for 40 hour exposure to control conditions.

Table III(b) - Solar cell array property changes over exposure to 40 hour cold gas from an unpowered arcjet.

\begin{tabular}{|c|c|c|c|}
\hline Characteristic & Units & Initial Property & Final Property \\
\hline $\begin{array}{c}\text { Short Circuit Current } \\
( \pm 1 \%)\end{array}$ & $\mathrm{mA}$ & 1176 & 1186 \\
\hline $\begin{array}{c}\text { Open Circuit Voltage } \\
( \pm 0.1 \%)\end{array}$ & $\mathrm{mV}$ & 2217 & 2216 \\
\hline Maximum Power & $\mathrm{mW}$ & 2000 & 2010 \\
\hline Fill Factor & $\%$ & 76.8 & 76.4 \\
\hline Efficiency & $\%$ & 11.4 & 11.4 \\
\hline
\end{tabular}

Table IV - Initial and final property measurements for 40 hour exposure to powered arcjet conditions.

Table IV(a) - Initial and final surface properties of samples exposed for 40 hours to an arcjet

\begin{tabular}{|c|c|c|c|c|c|c|}
\hline $\begin{array}{c}\text { Sample } \\
\text { Number }\end{array}$ & $\begin{array}{c}\text { Initial } \\
\text { Absorptance } \\
( \pm 0.005)\end{array}$ & $\begin{array}{c}\text { Final } \\
\text { Absorptance } \\
( \pm 0.005)\end{array}$ & $\begin{array}{c}\text { Initial } \\
\text { Emittance } \\
( \pm 0.005)\end{array}$ & $\begin{array}{c}\text { Final } \\
\text { Emittance } \\
( \pm 0.005)\end{array}$ & $\begin{array}{c}\text { Initial } \\
\text { Resistance } \\
\text { (ohms) }\end{array}$ & $\begin{array}{c}\text { Final } \\
\text { Resistance } \\
\text { (ohms) }\end{array}$ \\
\hline 1 & $0.107^{*}$ & $0.090^{* *}$ & $0.810^{*}$ & $0.800^{* *}$ & $0.5 \times 10^{6} \dagger$ & $3.0 \times 10^{7} \dagger$ \\
\hline 2 & $0.198^{*}$ & $0.192^{* *}$ & $0.900^{*}$ & $0.905^{* *}$ & $10^{10}$ & $10^{10}$ \\
\hline 3 & $0.970^{*}$ & $0.974^{* *}$ & $0.900^{*}$ & $0.908^{* *}$ & $10^{11}$ & $10^{11}$ \\
\hline 4 & $0.339^{*}$ & $0.332^{* *}$ & $0.540^{*}$ & $0.518^{* *}$ & - & - \\
\hline 5 & $0.127^{*}$ & $0.128^{* *}$ & $0.920^{*}$ & $0.917^{* *}$ & $2.0 \times 10^{8}$ & $3.1 \times 10^{7}$ \\
\hline 6 & $0.960^{*}$ & $0.959^{* *}$ & $0.915^{*}$ & $0.913^{* *}$ & - & - \\
\hline 7 & 0.042 & 0.042 & 0.802 & 0.798 & - & - \\
\hline 8 & 0.940 & 0.940 & 0.897 & 0.895 & $1.2 \times 10^{7}$ & $1.1 \times 10^{7}$ \\
\hline 9 & 0.138 & 0.127 & 0.915 & 0.915 & $2.4 \times 10^{7}$ & $4.7 \times 10^{7}$ \\
\hline 10 & 0.201 & 0.200 & 0.899 & 0.897 & $10^{10}$ & $10^{10}$ \\
\hline
\end{tabular}

* Typical optical properties of samples.

** Measured after both control and powered arcjet conditions.

$\dagger$ Measured from sample surface to mounting bracket.

Table IV(b) - Solar cell array property changes over 40 hour exposure to arcjet.

\begin{tabular}{|c|c|c|c|c|}
\hline Characteristic & Units & Initial Property & Final Property* & Final Property** \\
\hline $\begin{array}{c}\text { Short Circuit Current } \\
( \pm 1 \%)\end{array}$ & $\mathrm{mA}$ & 1186 & 1190 & 1180 \\
\hline $\begin{array}{c}\text { Open Circuit Voltage } \\
( \pm 0.1 \%)\end{array}$ & $\mathrm{mV}$ & 2216 & 2160 & 2216 \\
\hline Maximum Power & $\mathrm{mW}$ & 2010 & 1930 & 2010 \\
\hline Fill Factor & $\%$ & 76.4 & 75.2 & 76.8 \\
\hline Efficiency & $\%$ & 11.4 & 11.0 & 11.4 \\
\hline
\end{tabular}

* No thermal control

** With thermal control 
Table V - Initial and final property measurements for electrostatic discharge characterization tests.

Table V(a) - Initial and final surface properties of electrostatic discharge characterization test samples.

\begin{tabular}{|c|c|c|c|c|}
\hline $\begin{array}{c}\text { Sample } \\
\text { Type }\end{array}$ & $\begin{array}{c}\text { Initial } \\
\text { Absorptance } \\
( \pm 0.005)\end{array}$ & $\begin{array}{c}\text { Final } \\
\text { Absorptance } \\
( \pm 0.005)\end{array}$ & $\begin{array}{c}\text { Initial } \\
\text { Emittance } \\
( \pm 0.005)\end{array}$ & $\begin{array}{c}\text { Final } \\
\text { Emittance } \\
( \pm 0.005)\end{array}$ \\
\hline OSR & 0.042 & 0.042 & 0.798 & 0.797 \\
\hline S13GLO & 0.200 & 0.203 & 0.897 & 0.897 \\
\hline
\end{tabular}

Table $V(b)$ - Solar cell array property changes for electrostatic discharge characterization testing.

\begin{tabular}{|c|c|c|c|}
\hline Characteristic & Units & Initial Property & Final Property \\
\hline $\begin{array}{c}\text { Short Circuit Current } \\
( \pm 1 \%)\end{array}$ & $\mathrm{mA}$ & 1180 & 1182 \\
\hline $\begin{array}{c}\text { Open Circuit Voltage } \\
( \pm 0.1 \%)\end{array}$ & $\mathrm{mV}$ & 2216 & 2218 \\
\hline Maximum Power & $\mathrm{mW}$ & 2010 & 2000 \\
\hline Fill Factor & $\%$ & 76.8 & 76.4 \\
\hline Efficiency & $\%$ & 11.4 & 11.4 \\
\hline
\end{tabular}

Table VI - Conducted voltage transients.

\begin{tabular}{|c|c|c|c|c|c|c|c|}
\hline \multirow{2}{*}{ Event } & \multicolumn{2}{|c|}{ Primary power } & \multicolumn{2}{c|}{ CMD "ON" line } & \multicolumn{2}{c|}{$\begin{array}{c}\text { Arc current telemetry } \\
\text { line }\end{array}$} \\
\cline { 2 - 8 } & \multicolumn{2}{|c|}{ Level (V) } & $\begin{array}{c}\text { Duration* } \\
(\mu \mathrm{s})\end{array}$ & $\begin{array}{c}\text { Amplitude** } \\
(\mathrm{V})\end{array}$ & $\begin{array}{c}\text { Duration* } \\
(\mu \mathrm{s})\end{array}$ & $\begin{array}{c}\text { Amplitude** } \\
(\mathrm{V})\end{array}$ & $\begin{array}{c}\text { Duration* } \\
(\mu \mathrm{s})\end{array}$ \\
\cline { 2 - 7 } & Max & Min & 2.3 & $<2$ & 2 & $<2$ \\
\hline $\begin{array}{c}\text { Auxiliary } \\
\text { On }\end{array}$ & +123 & +78 & $<5$ & 8 & $<2$ & 14 & $<1$ \\
\hline Main On & +15.1 & -14 & $<5$ & - & - & $3.5 \dagger$ & $<2$ \\
\hline Arc start & +98.7 & +93.7 & $<2$ & -2.6 & 6.3 & $<3$ \\
\hline $\begin{array}{c}\text { PPU } \\
\text { switching }+\dagger\end{array}$ & +98.5 & +93.5 & $<3$ & 5.6 & $<3$ & & \\
\hline
\end{tabular}

* Spike duration measured from $20 \%$ leading edge to $20 \%$ training edge amplitude points. ** Peak to peak amplitudes.

$\dagger$ First power processing unit switching spike.

t† Measured using DC power supply for primary power. 


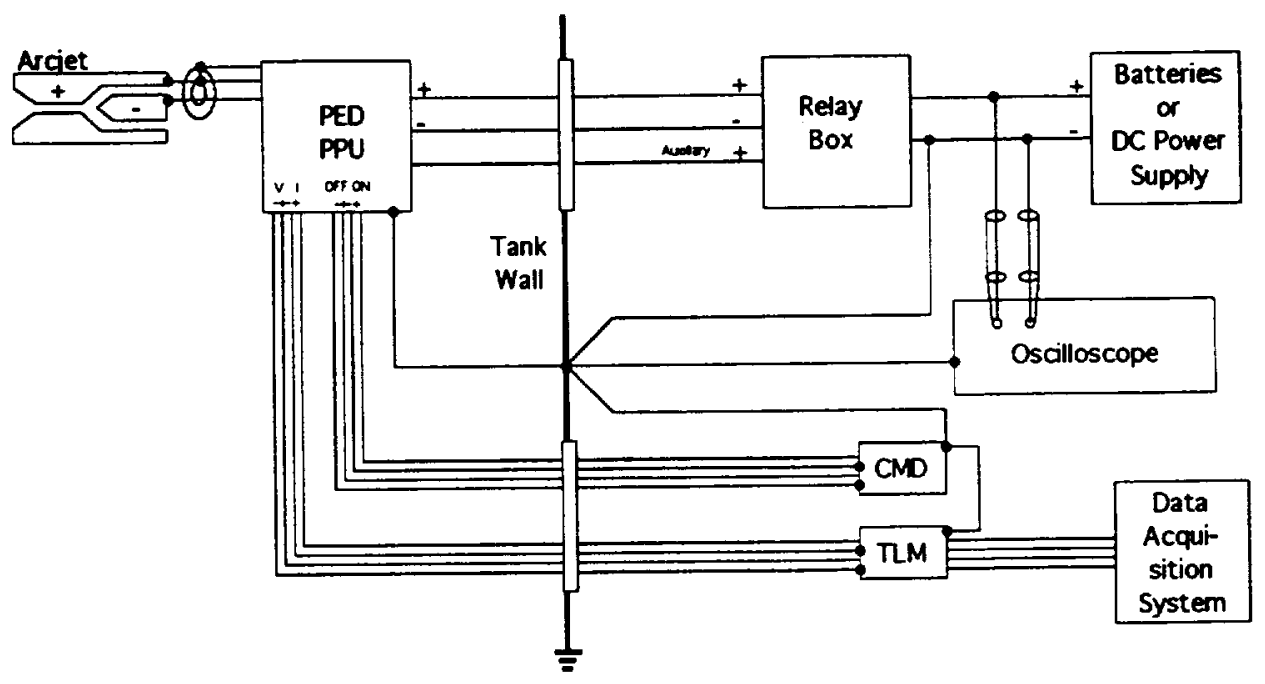

Figure 1 - Arcjet system electrical schematic.

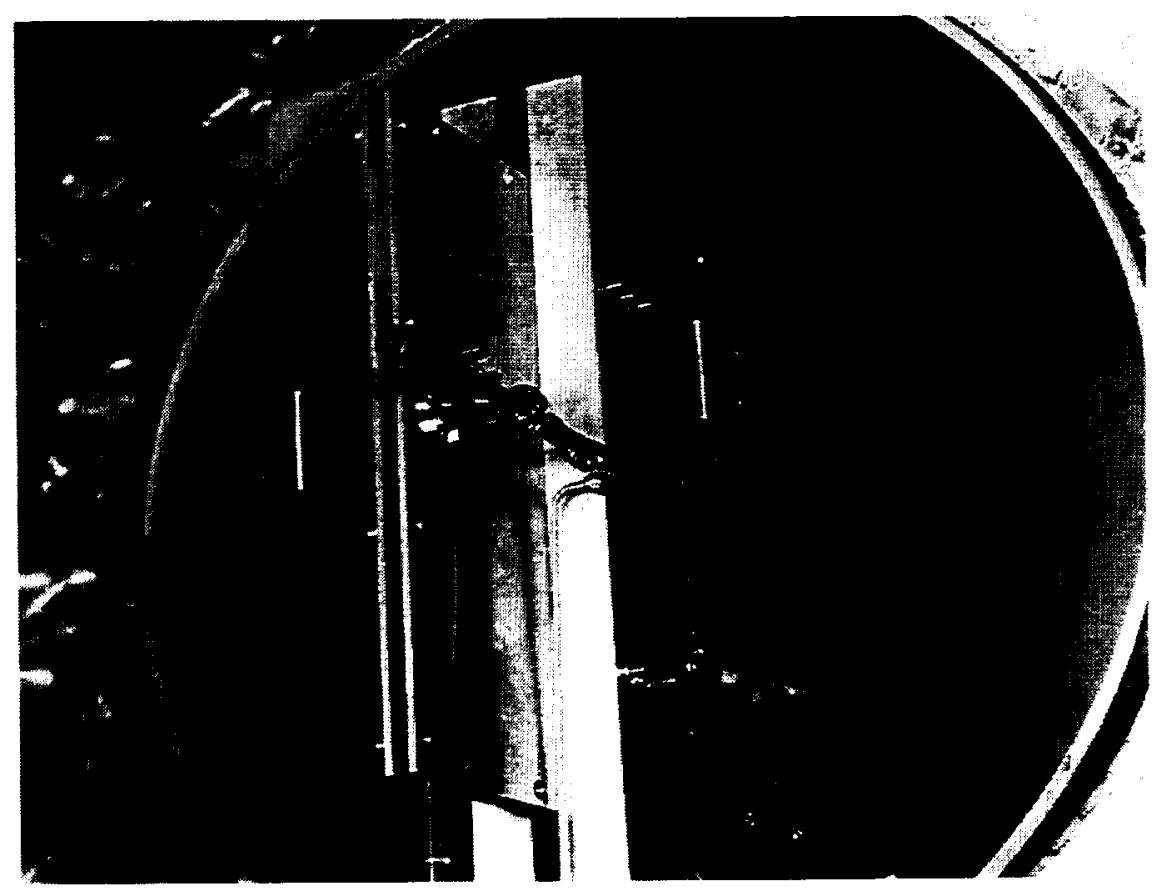

Figure 2 - Arcjet and PPU mounted to cold plate inside vacuum chamber. 


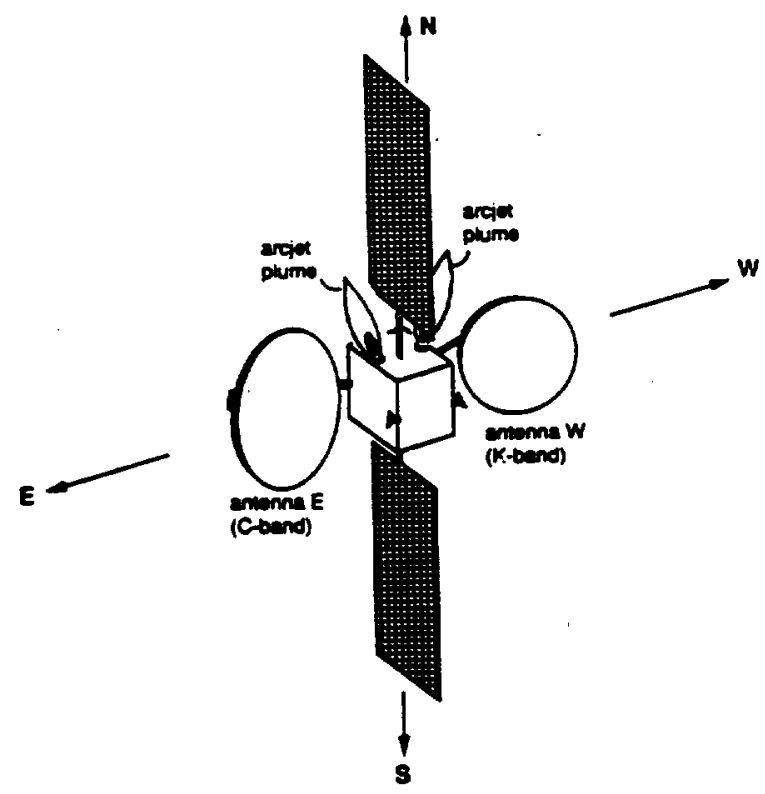

Figure 3 - Diagram showing location of arcjets on Series 7000 communications satellite.
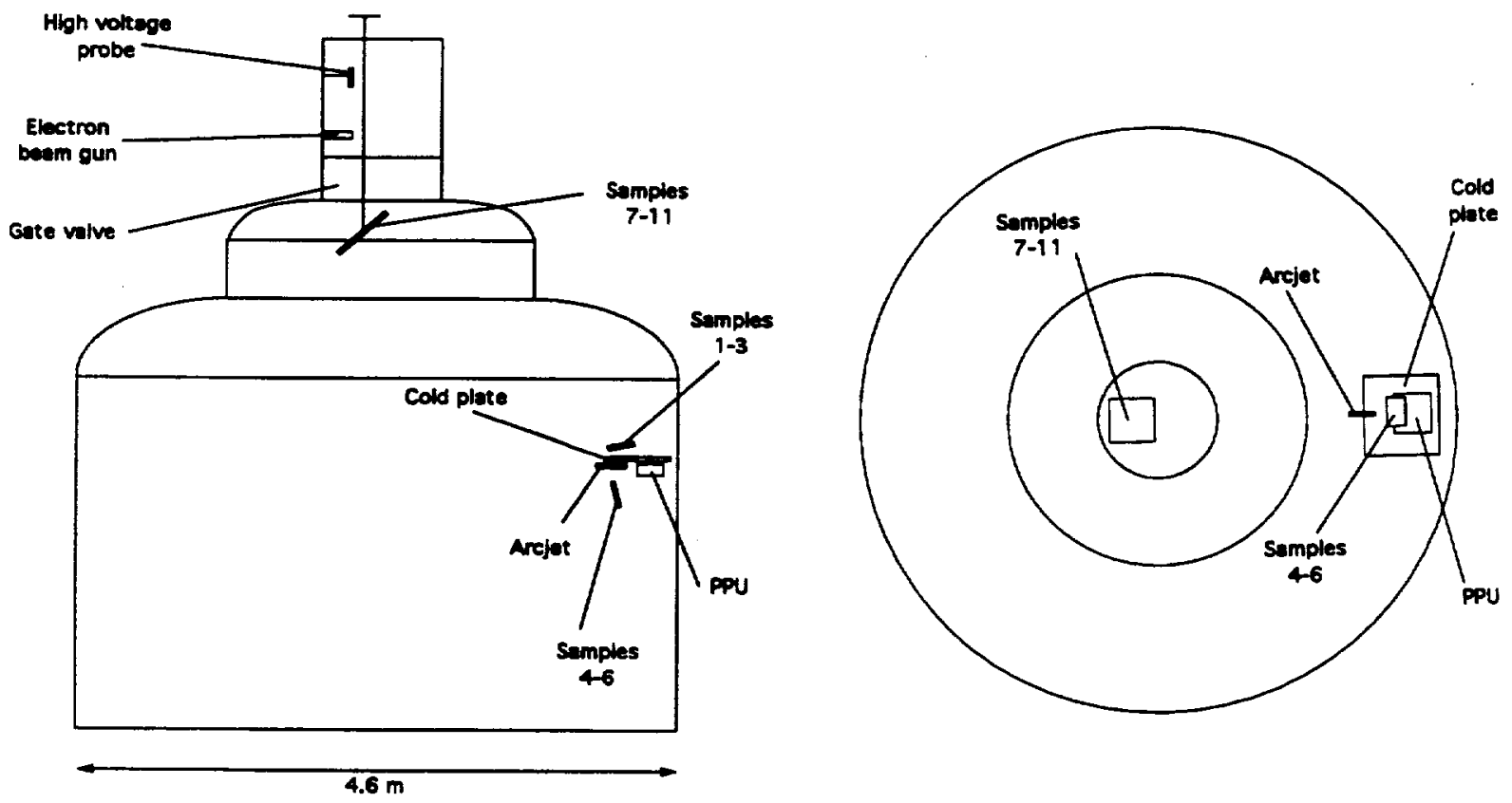

Figure 4(a) - Schematic top view.

Figure 4(b) - Schematic cross section.

Figure 4 - Spacecraft material contamination test schematic. 


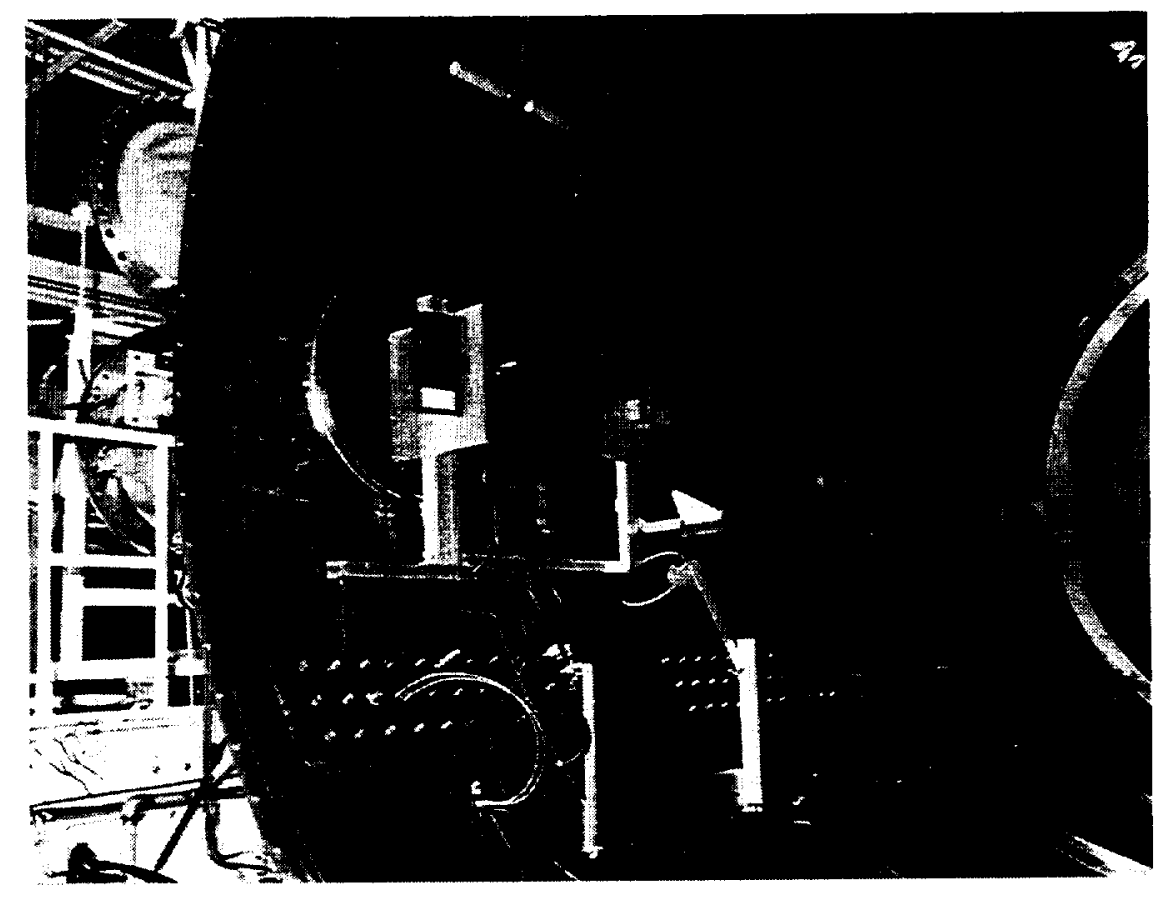

Figure 5 - Test setup showing spacecraft materials and antenna array.

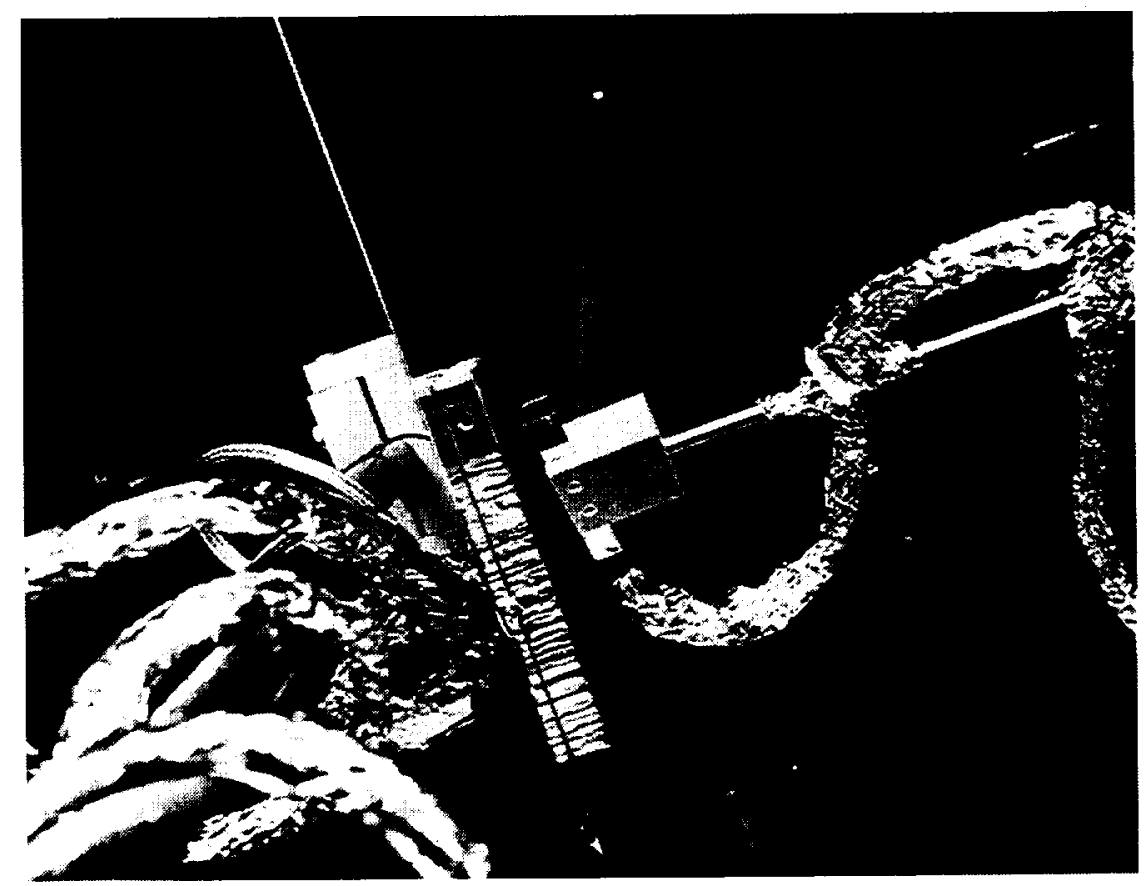

Figure 6 - High voltage probe measuring surface potential of an optical solar reflector. 


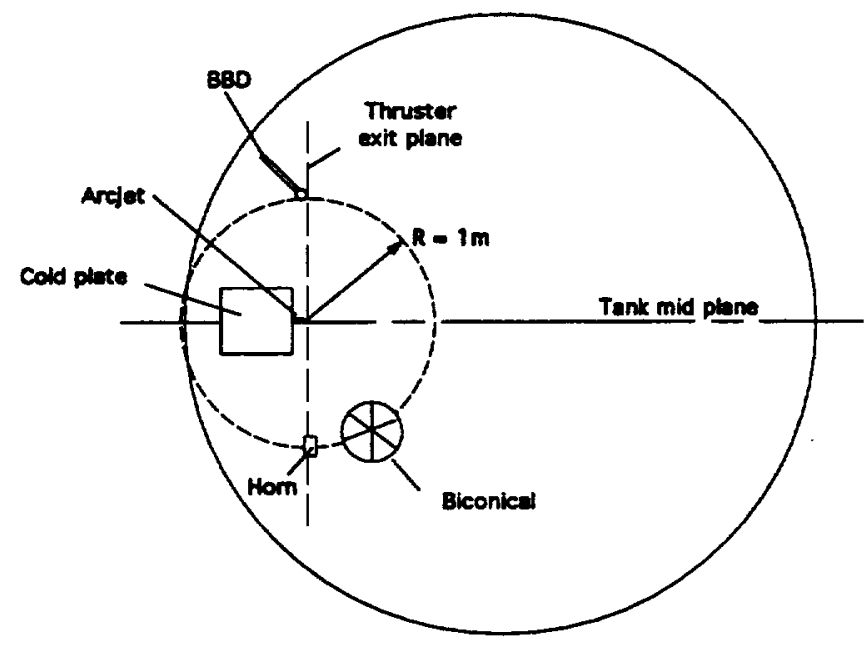

Figure 7 (a) - Schematic tank cross section.

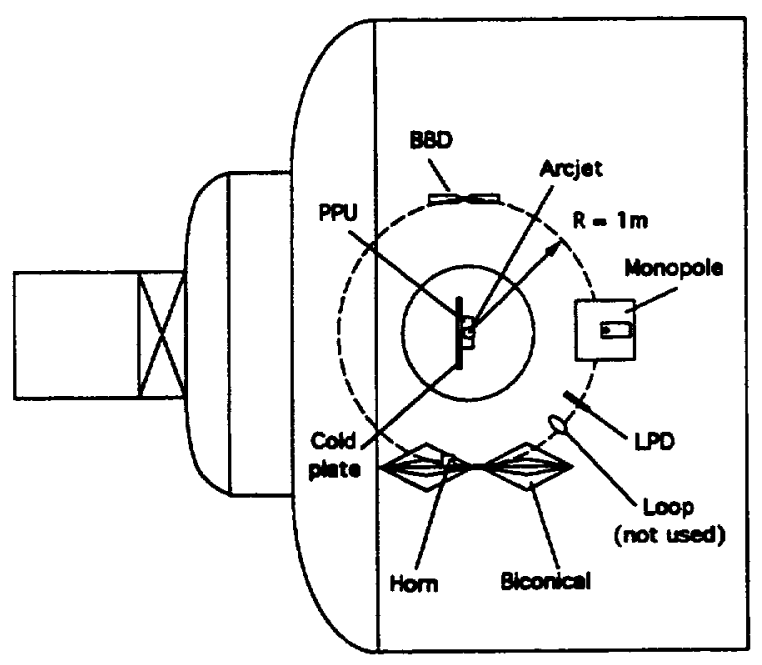

Figure 7(b) - Schematic tank side view.

Figure 7 - Schematic of antenna array for electromagnetic interference tests.

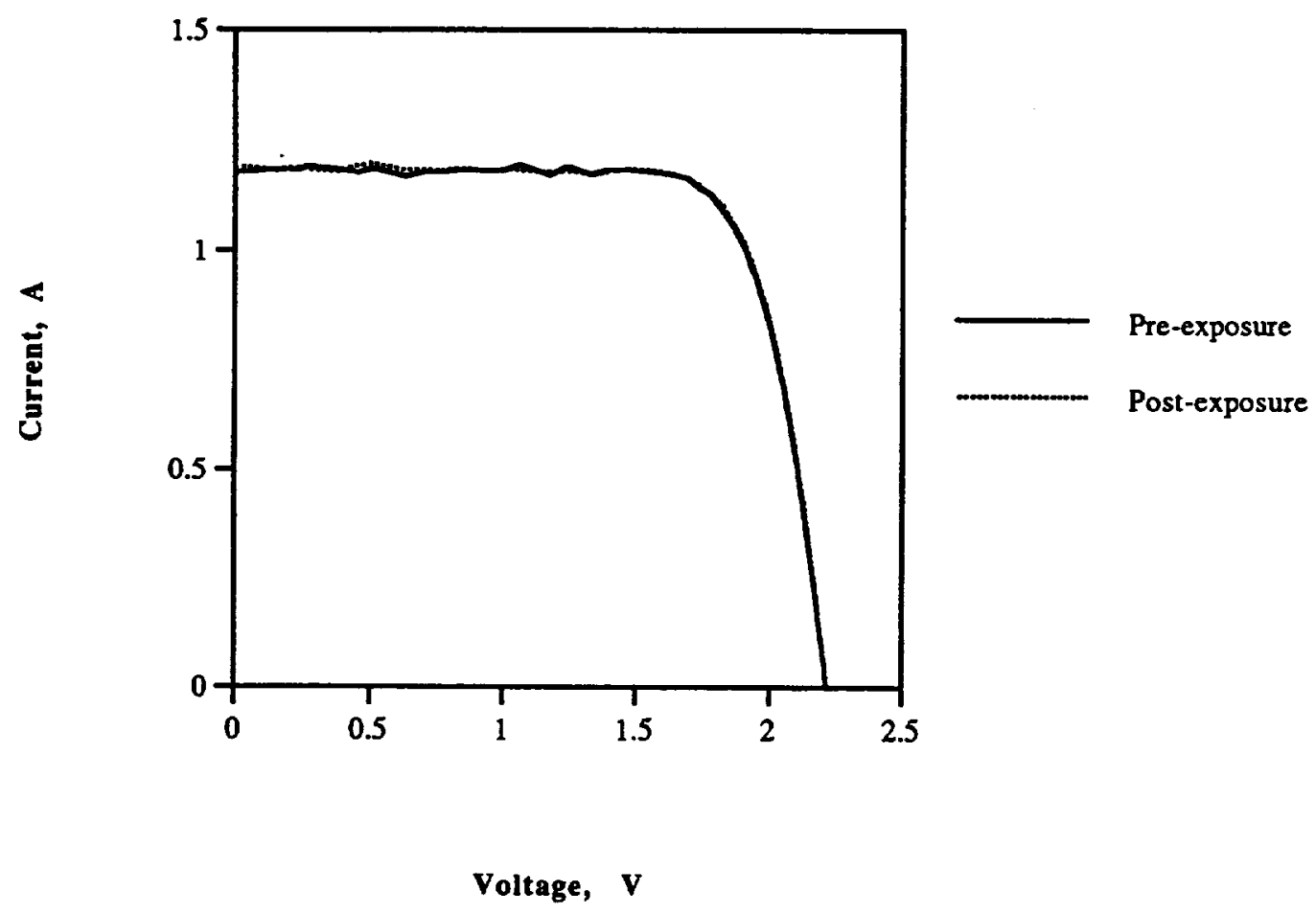

Figure 8(a) - Pre and post cold gas arcjet exposure.

Figure 8 - Current-voltage curves for $4 \times 4$ silicon solar cell array. 


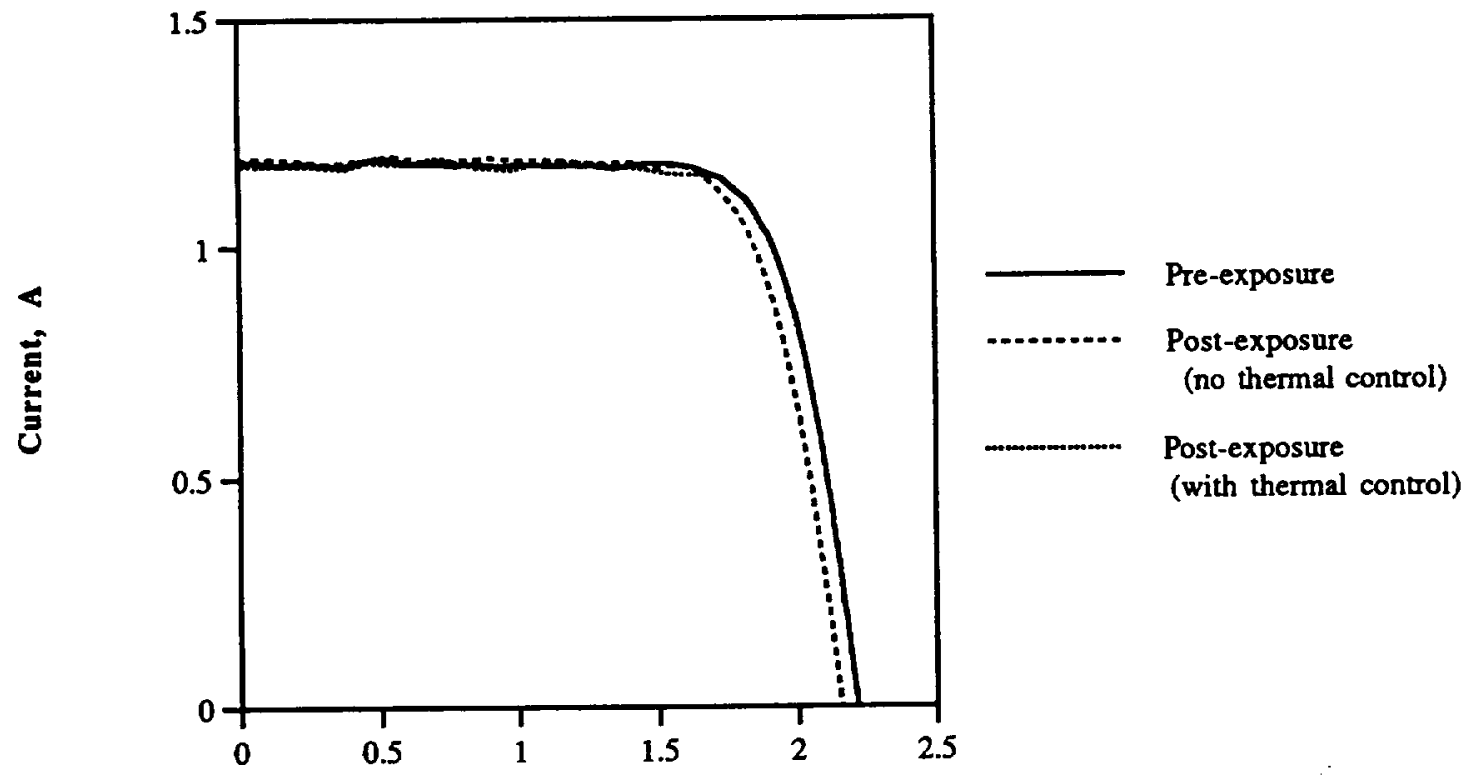

Voltage, $\quad \mathrm{V}$

Figure 8(b) - Pre and post powered arcjet exposure.

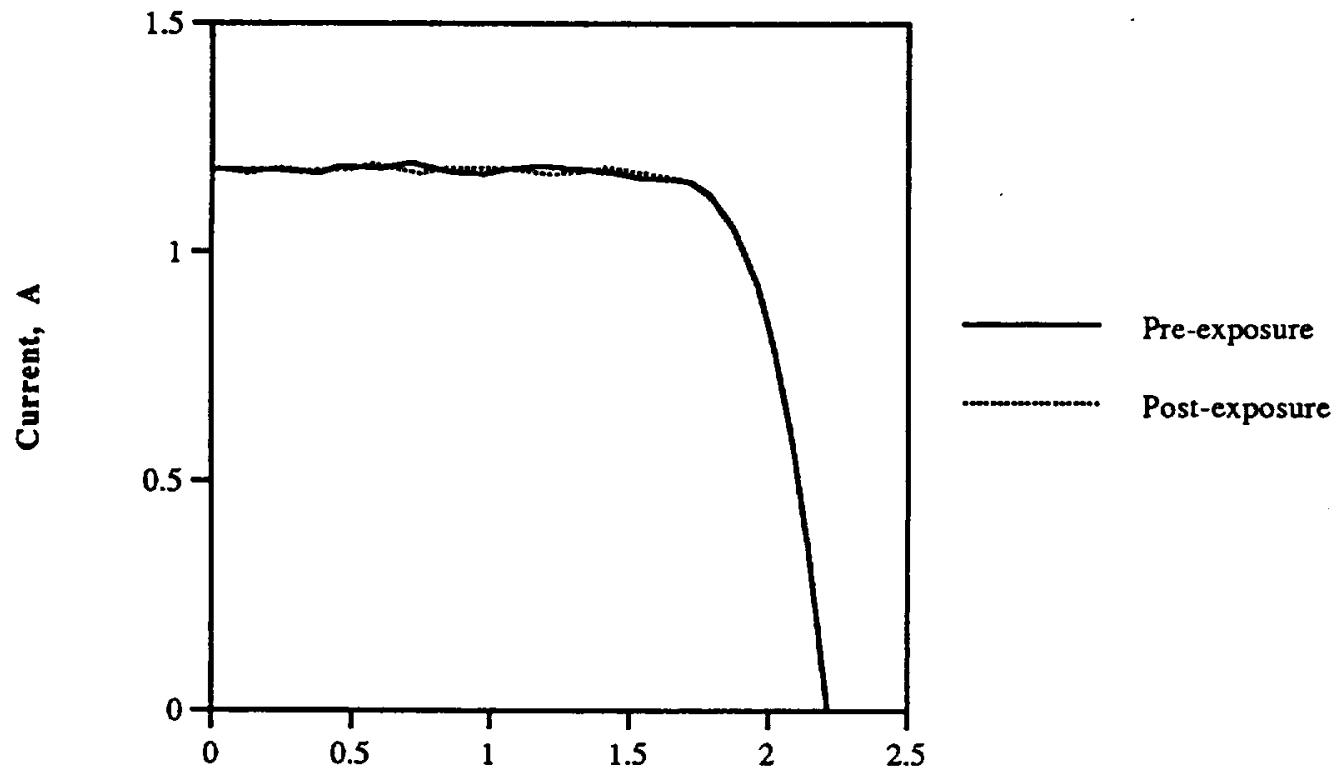

Voltage, $\quad \mathbf{V}$

Figure 8(c) - Pre and post electrostatic discharge test exposure.

Figure 8 - Current-voltage curves for $4 \times 4$ silicon solar cell array. 


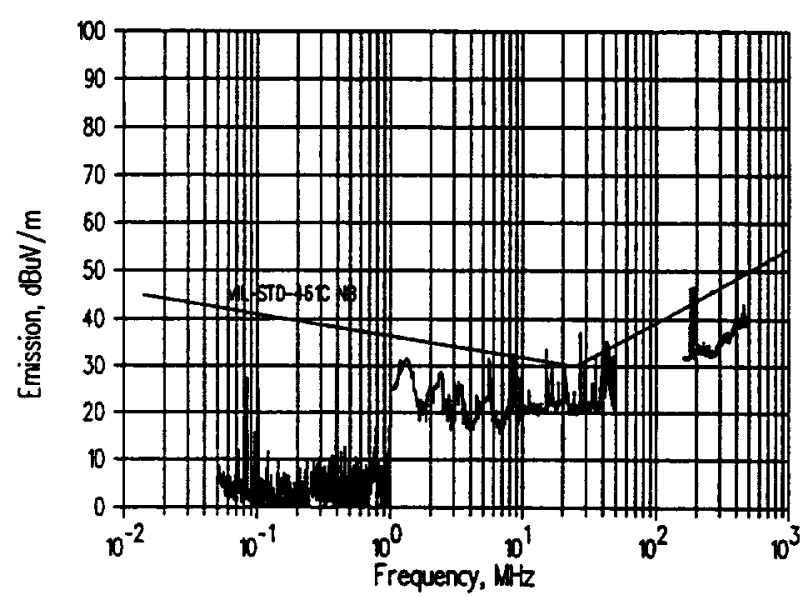

Figure 9(a) - Ambient conditions (Arcjet/PPU off).

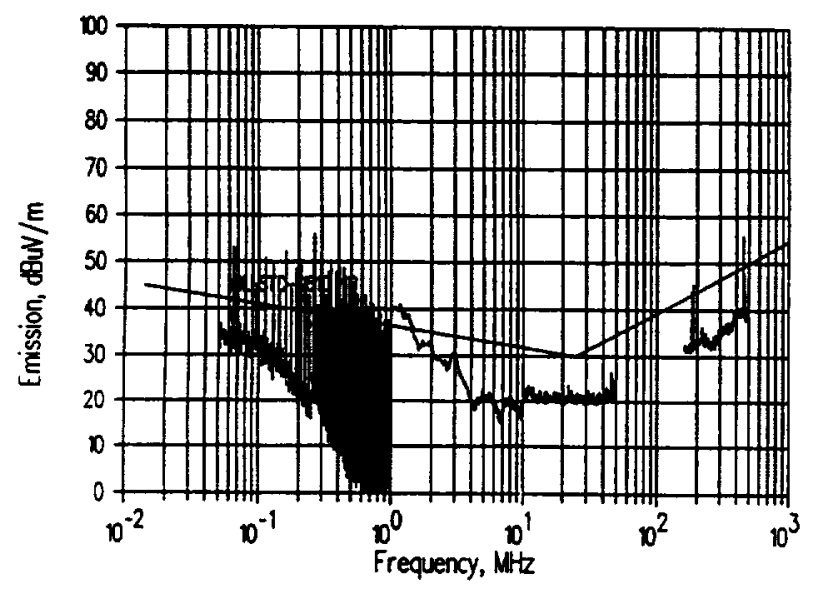

Figure 9(b) - Arcjet/PPU A emissions.

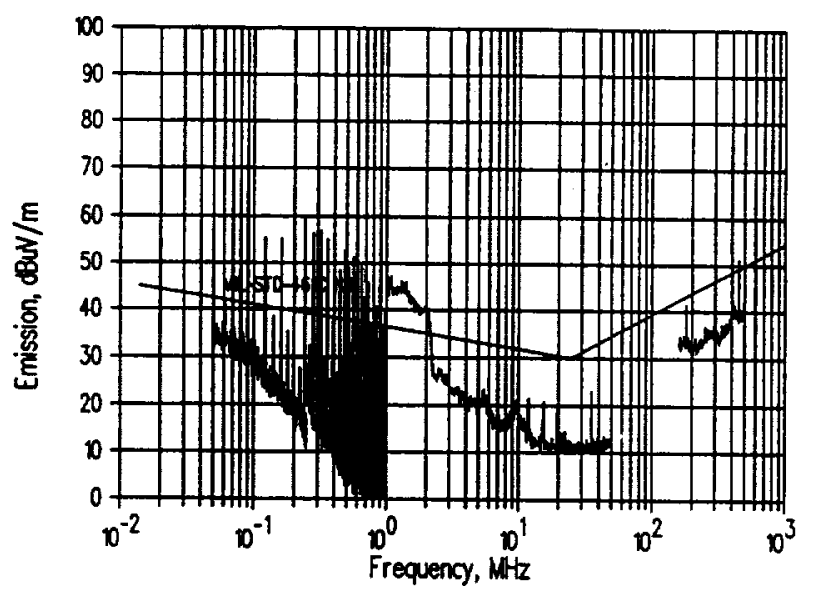

Figure 9(c) - Arcjet/PPU B emissions.

Figure 9 - Narrowband radiated emissions.

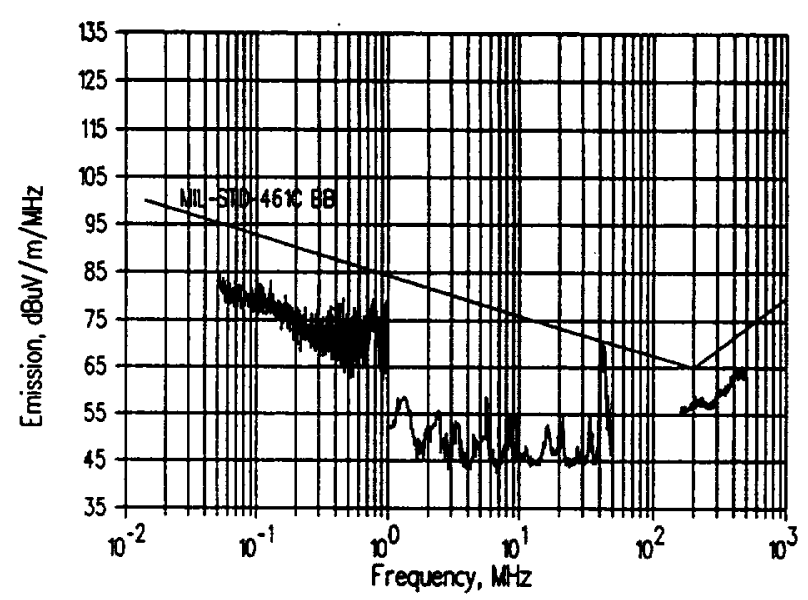

Figure 10(a) - Ambient conditions (Arcjet/PPU off).

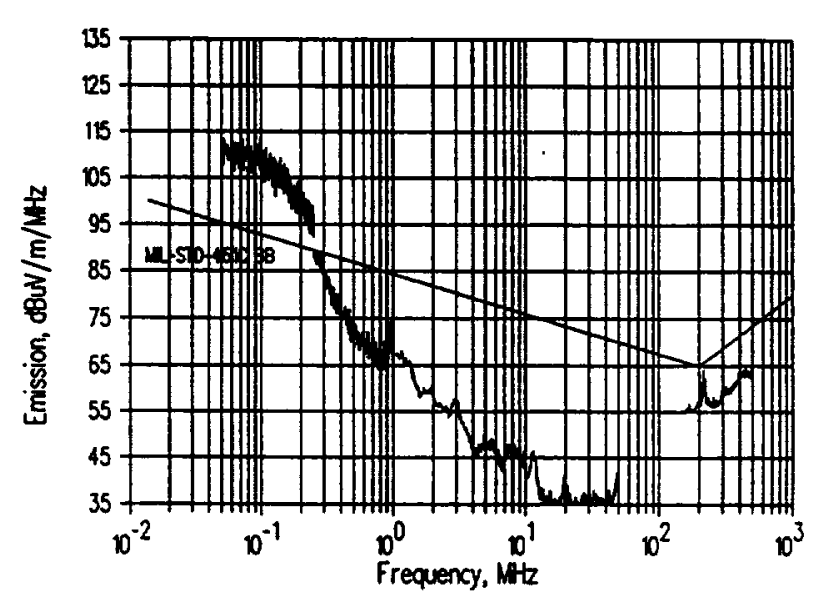

Figure 10(b) - Arcjet/PPU A emissions.

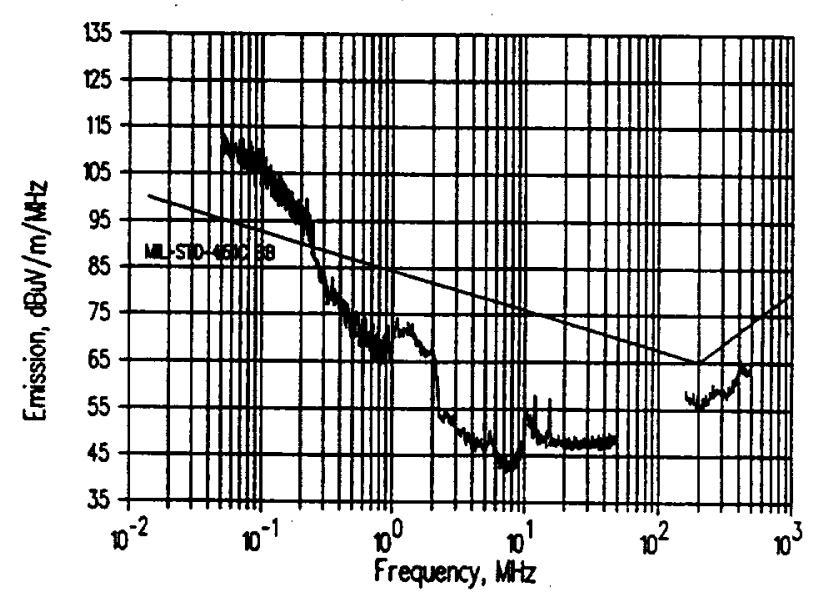

Figure 10(c) - Arcjet/PPU B emissions.

Figure 10 - Broadband radiated emissions. 


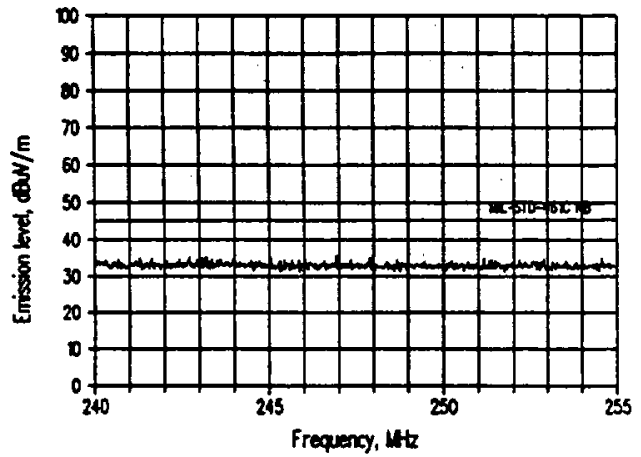

Figure 11(a) - Ambient narrowband conditions.

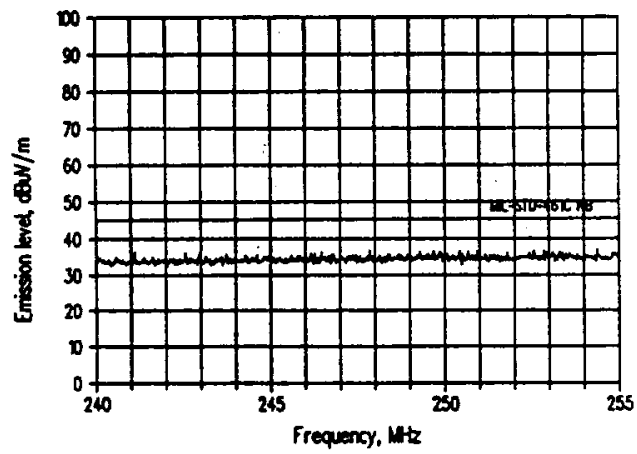

Figure 11(b) - Arcjet/PPU B narrowband emissions.

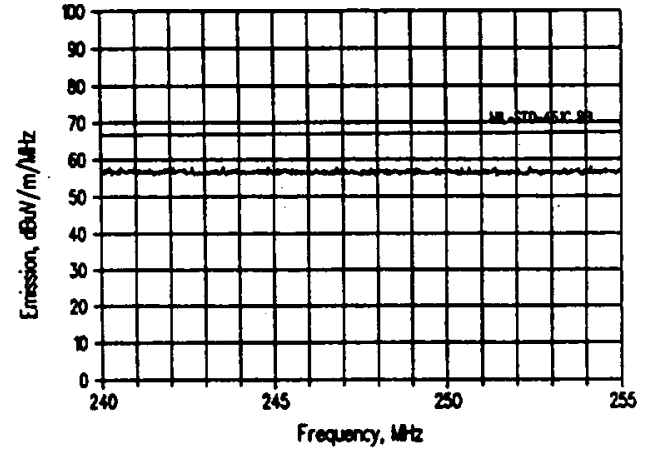

Figure 11(c) - Ambient broadband conditions.

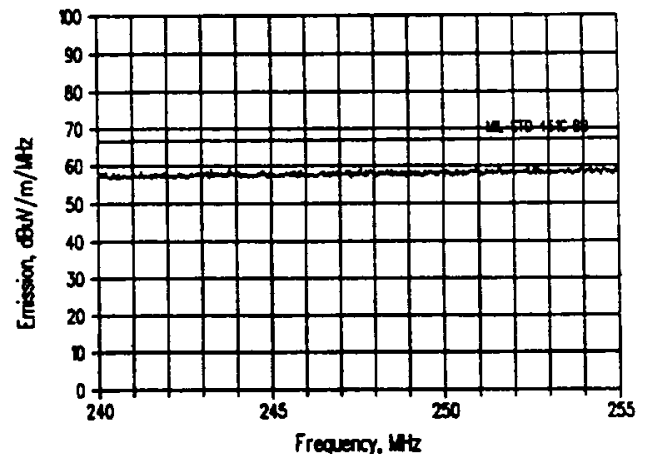

Figure 11 - Narrowband and broadband radiated emissions in the UHF band.

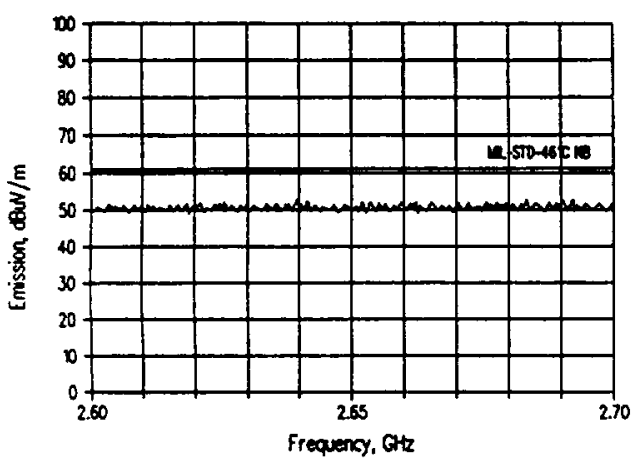

Figure 12(a) - Ambient narrowband conditions.

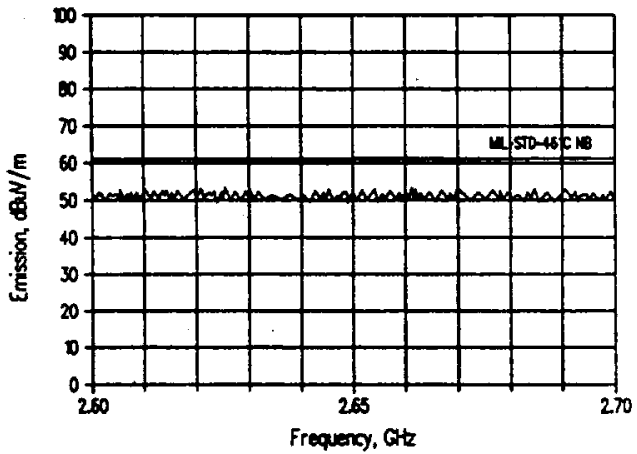

Figure 12(b) - PPU B narrowband conditions.

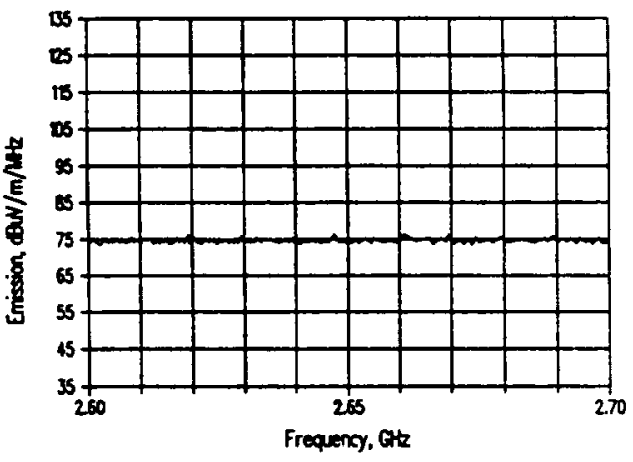

Figure 12(c) - Ambient broadband conditions.

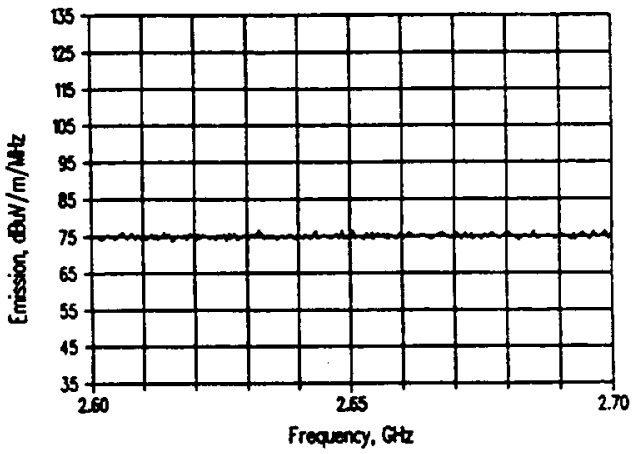

Figure 12(d) - PPU B broadband conditions.

Figure 12 - Narrowband and broadband radiated emissions in the $S$ band. 


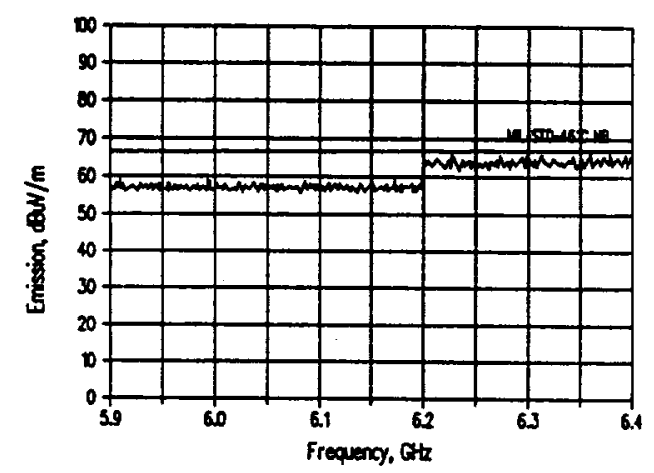

Figure 13(a) - Ambient narrowband conditions.

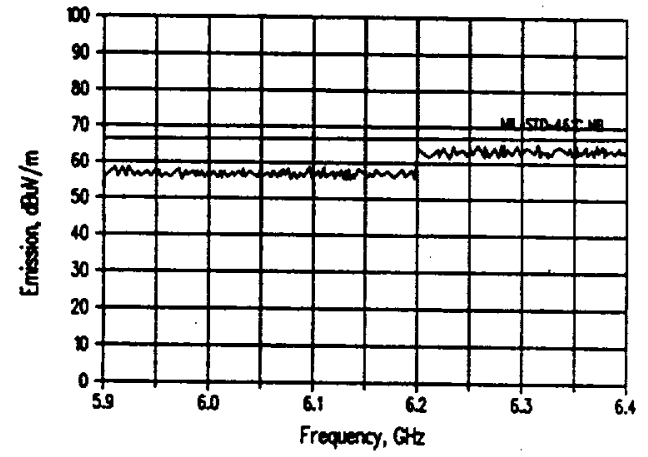

Figure 13(b) - Arcjet/PPU B narrowband emissions.

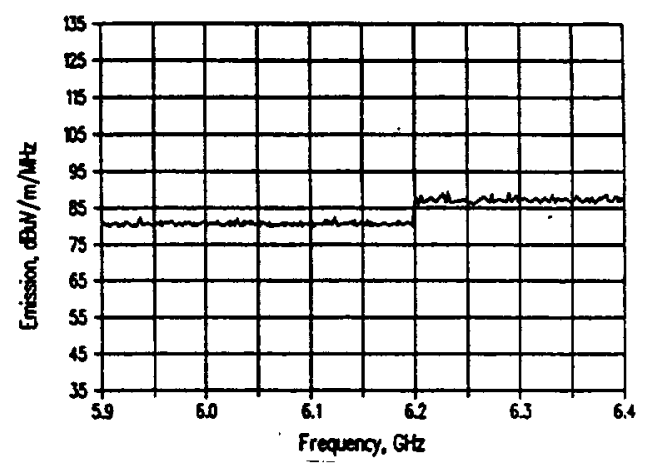

Figure 13(c) - Ambient broadband conditions.

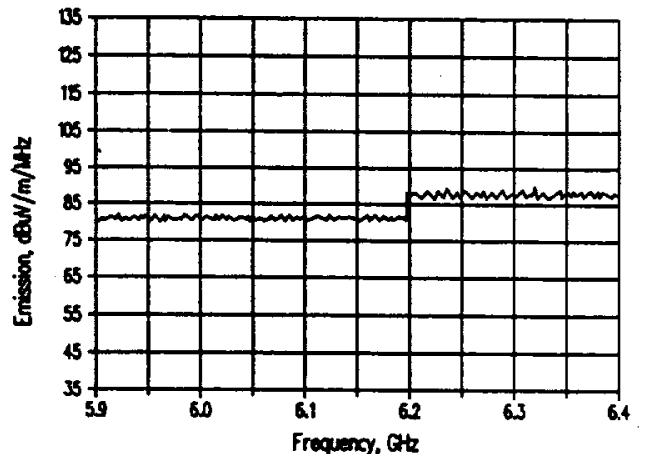

Figure 13 - Narrowband and broadband radiated emissions in the $C$ band.

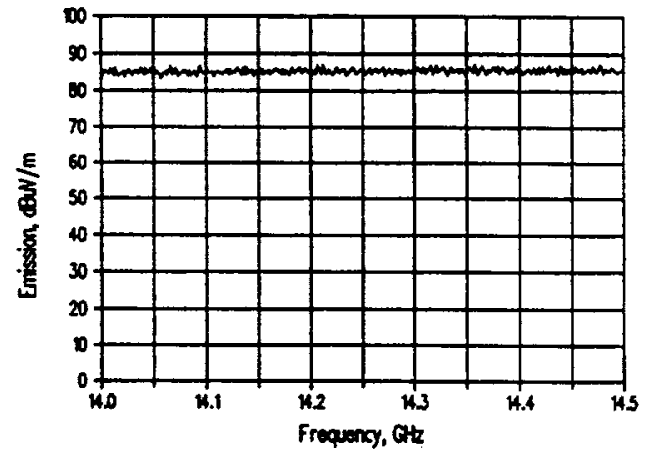

Figure 14(a) - Ambient narrowband conditions.

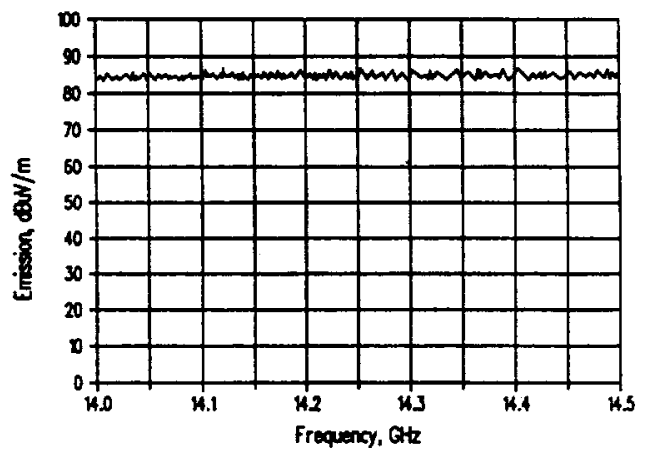

Figure 14(b) - Arcjet/PPU B narrowband emissions.

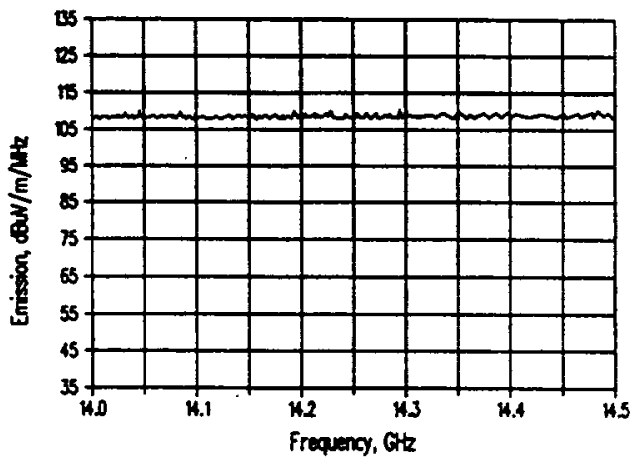

Figure 14(c) - Ambient broadband conditions.

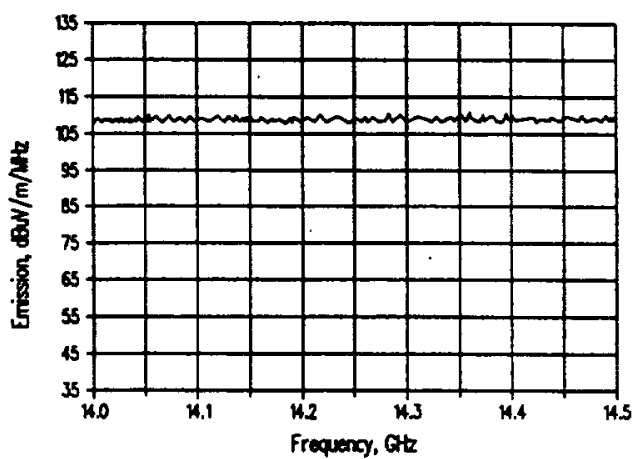

Figure 14 - Narrowband and broadband radiated emissions in the Ku band. 


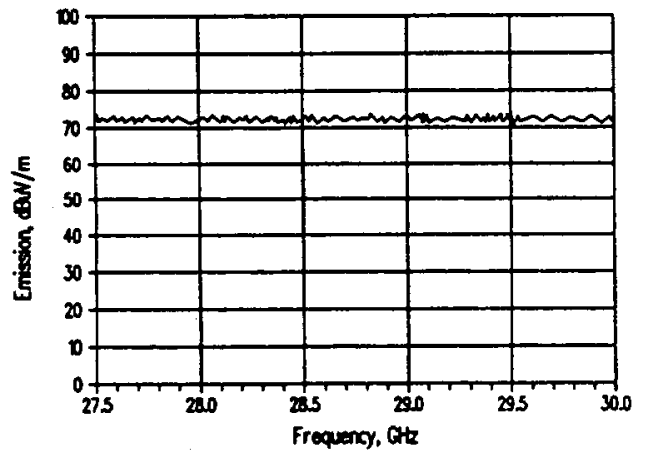

Figure 15(a) - Ambient narrowband conditions.

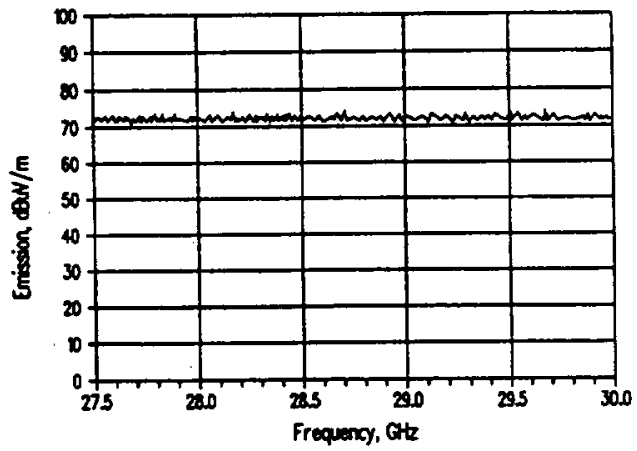

Figure 15(b) - Arcjet/PPU B narrowband emissions.

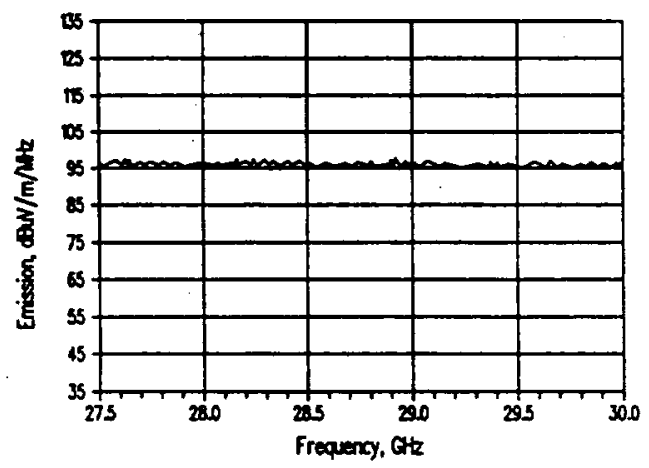

Figure 15(c) - Ambient broadband conditions.

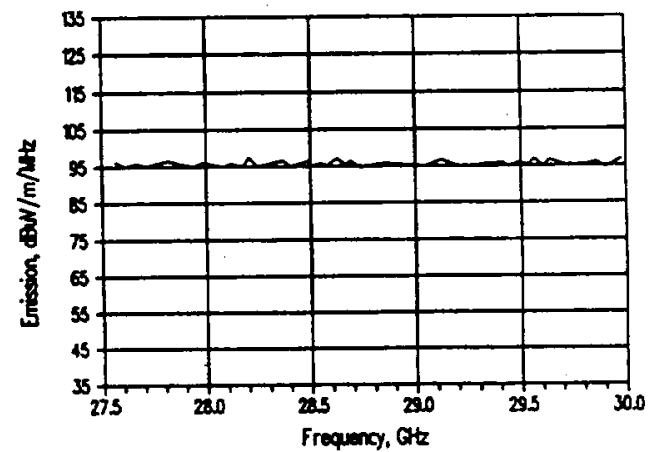

Figure 15(d) - Arcjet/PPU B broadband emissions.

Figure 15 - Narrowband and broadband radiated emissions in the Ka band.

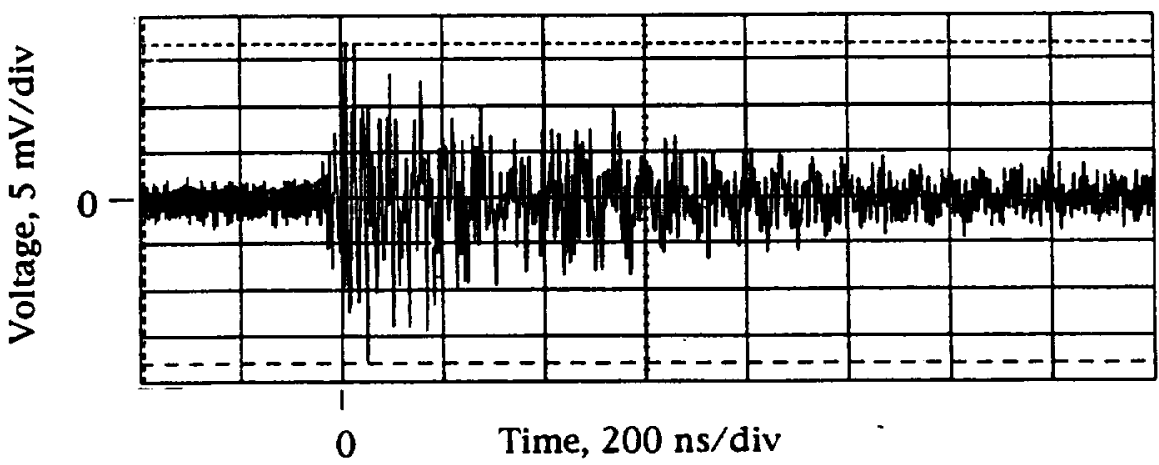

Figure 16(a) - Arc ignition transient over extended time scale.

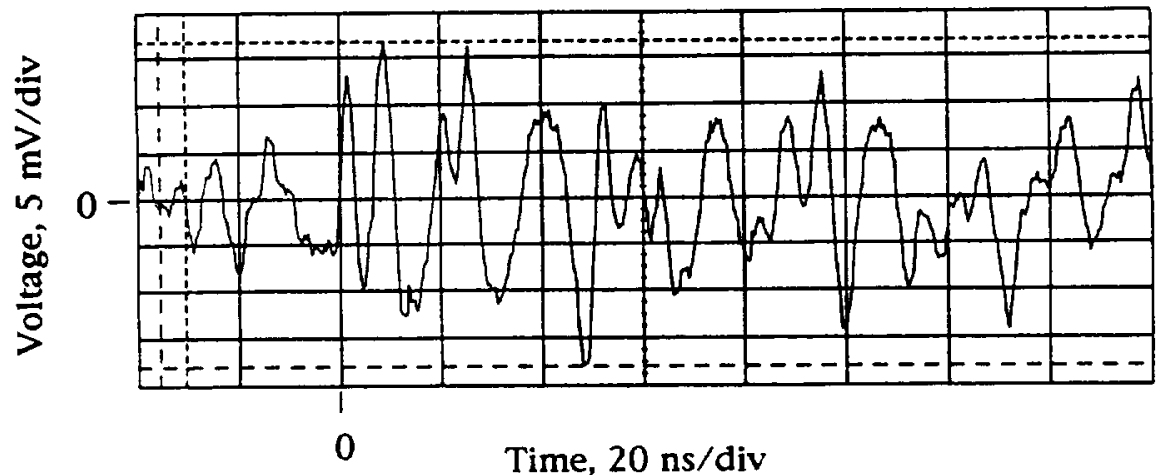

Figure 16(b) - Arc ignition transient expanded time scale.

Figure 16 - Arc ignition transient captured with biconical antenna (20 to $300 \mathrm{MHz}$ ). 


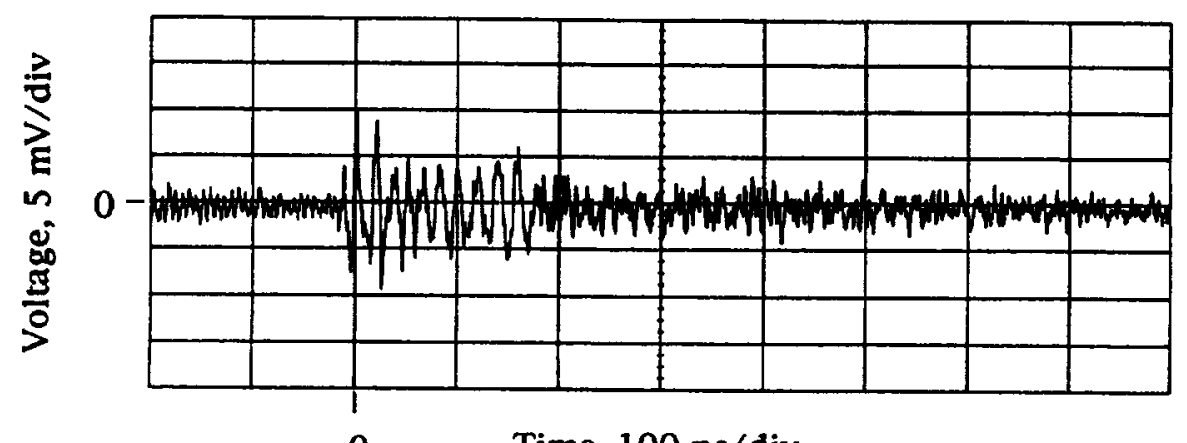

Figure 17(a) - Arc ignition transient over extended time scale.

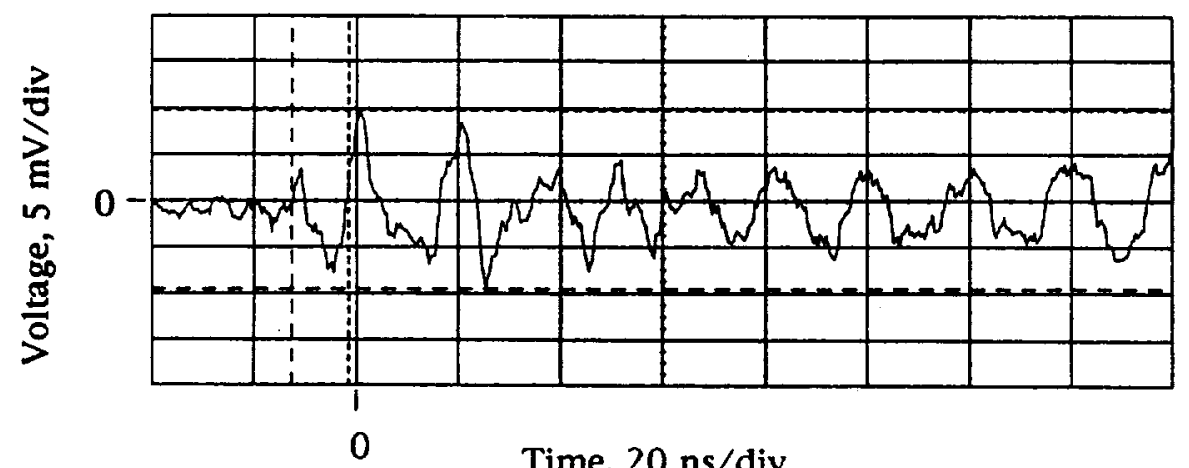

Figure 17(b) - Arc ignition transient expanded time scale.

Figure 17 - Arc ignition transient captured with broadband dipole antenna (160 to $500 \mathrm{MHz}$ ).

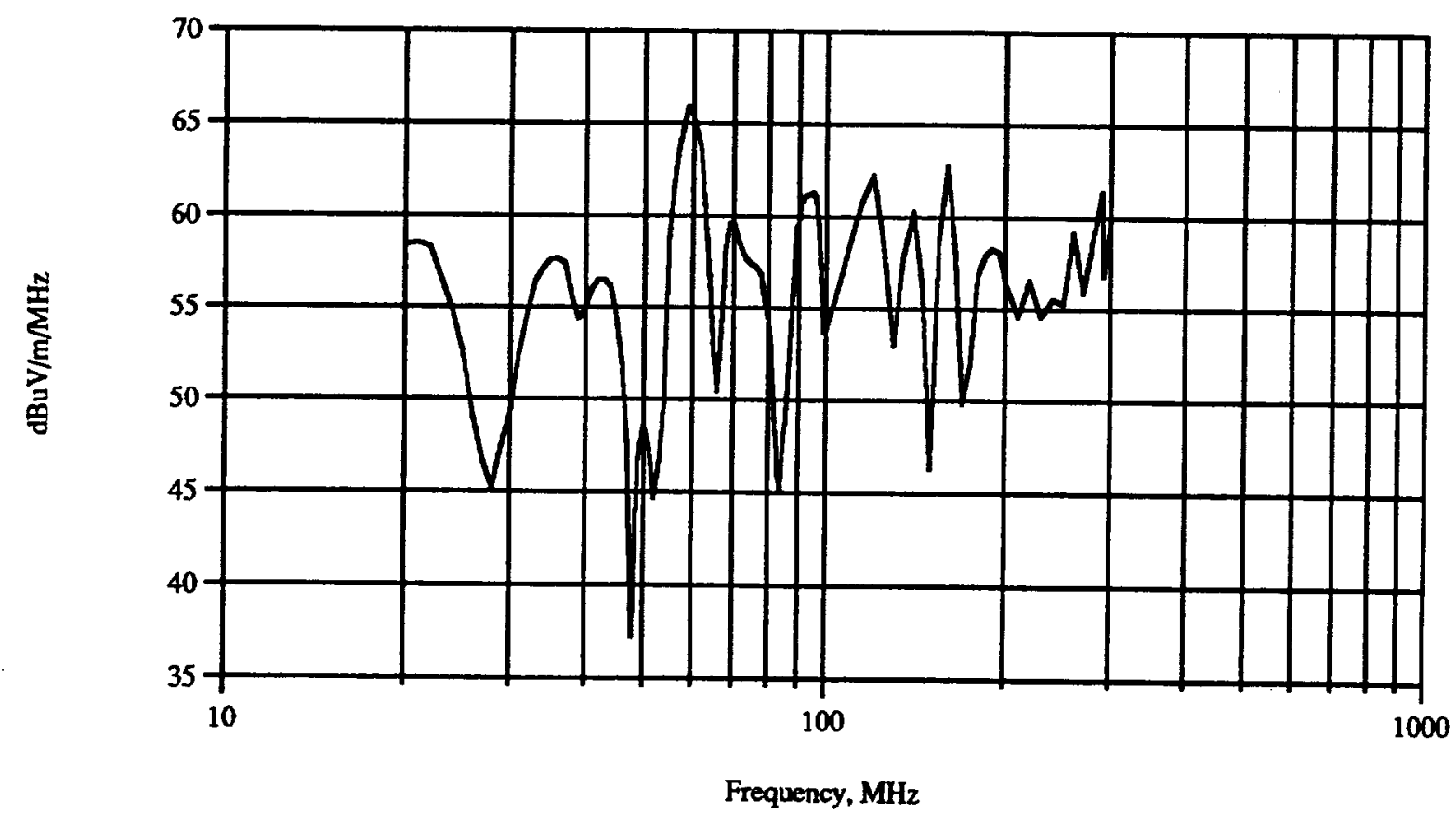

Figure 18 - Fourier spectrum of arc ignition transient shown in Figure 16(b). 


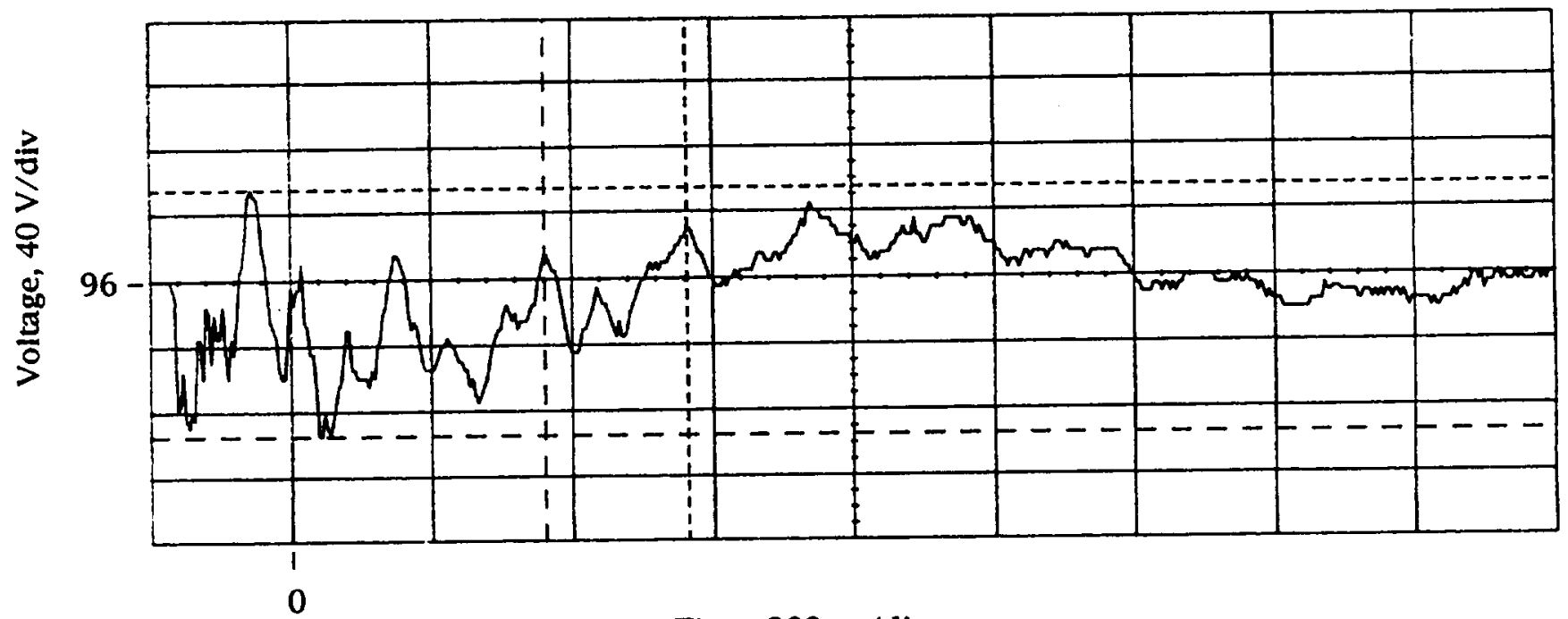

Time, $200 \mathrm{~ns} / \mathrm{div}$

Figure 19 - Startup conducted voltage transient on primary power line for main power application to PPU B. 


\begin{tabular}{|c|c|c|}
\hline \multicolumn{2}{|c|}{ REPORT DOCUMENTATION PAGE } & $\begin{array}{l}\text { Form Approved } \\
\text { OMB No. 0704-0188 }\end{array}$ \\
\hline \multicolumn{3}{|c|}{ 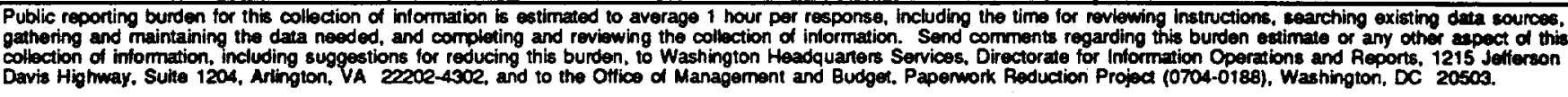 } \\
\hline 1. AGENCY USE ONLY (Leave blank) & $\begin{array}{l}\text { 2. REPORT DATE } \\
\text { June } 1993\end{array}$ & $\begin{array}{l}\text { J DATES COVERED } \\
\text { echnical Memorandum }\end{array}$ \\
\hline \multicolumn{2}{|c|}{$\begin{array}{l}\text { 4. TITLE AND SUBTITLE } \\
\text { Low Power Arcjet System Spacecraft Impacts }\end{array}$} & 5. FUNDING NUMBERS \\
\hline \multicolumn{3}{|c|}{$\begin{array}{l}\text { Eric J. Pencil, Charles J. Sarmiento, D.A. Lichtin, } \\
\text { J.W. Palchefsky, and A.L. Bogorad }\end{array}$} \\
\hline \multicolumn{2}{|c|}{$\begin{array}{l}\text { National Aeronautics and Space Administration } \\
\text { Lewis Research Center } \\
\text { Cleveland, Ohio } 44135-3191\end{array}$} & $\begin{array}{l}\text { 8. PERFORMUNG ORGANIZATION } \\
\text { REPORT NUMBER } \\
\text { E-8048 }\end{array}$ \\
\hline \multicolumn{2}{|c|}{$\begin{array}{l}\text { National Aeronautics and Space Administration } \\
\text { Washington, D.C. } 20546-0001\end{array}$} & $\begin{array}{l}\text { 10. SPONSORING/MONITORING } \\
\text { AGENCY REPORT NUMBER } \\
\text { NASA TM-106307 } \\
\text { AIAA-93-2392 }\end{array}$ \\
\hline \multicolumn{3}{|c|}{$\begin{array}{l}\text { 11. SUPPLEMENTARY NOTES } \\
\text { Prepared for the 29th Joint Propulsion Conference and Exhibit cosponsored by the ALAA, SAE, ASME, and ASEE, Monterey, } \\
\text { California, June 28-30, 1993. Eric J. Pencil and Charles J. Sarmiento, NASA Lewis Research Center, D.A. Lichtin, J.W. Palchefsky, } \\
\text { and A.L. Bogorad, Martin Marietta Astro Space, Princeton, New Jersey 08543. Responsible person, Eric J. Pencil, (216) 433-7463. }\end{array}$} \\
\hline \multicolumn{2}{|c|}{$\begin{array}{l}\text { 12a. DISTRIBUTIONAVAILABILTY STATEMENT } \\
\text { Unclassified - Unlimited } \\
\text { Subject Category } 20\end{array}$} & 12b. DISTRIBUTION CODE \\
\hline
\end{tabular}

Application of electrothermal arcjets on communications satellites requires assessment of integration concerns identified by the user community. Perceived risks include plume contamination of spacecraft materials, induced arcing or electrostatic discharges between differentially charged spacecraft surfaces, and conducted and radiated electromagnetic interference (EMI) for both steady state and transient conditions. A Space Act agreement between Martin Marietta Astro Space, the Rocket Research Company, and NASA's Lewis Research Center was established to experimentally examine these issues. Spacecraft materials were exposed to an arcjet plume for 40 hours, representing 40 weeks of actual spacecraft life, and contamination was characterized by changes in surface properties. With the exception of the change in emittance of one sample, all measurable changes in surface properties resulted in acceptable end of life characteristics. Charged spacecraft samples were benignly and consistently reduced to ground potential during exposure to the powered arcjet plume, suggesting that the arcjet could act as a charge control device on spacecraft. Steady state EMI signatures obtained using two different power processing units were similar to emissions measured in a previous test. Emissions measured in UHF, S, C, Ku and $\mathrm{Ka}$ bands obtained a null result which verified previous work in the UHF, $S$, and $C$ bands. Characteristics of conducted and radiated transient emissions appear within standard spacecraft susceptibility criteria.

\section{SUBJECT TEAMS}

Arcjet thruster; Electromagnetic interference; Spacecraft materials; Integration testing; Electrostatic discharge; Electric propulsion

\begin{tabular}{|c|c|c|}
\hline $\begin{array}{c}\text { 17. SECURTY CLASSIFICATION } \\
\text { OF REPORT } \\
\text { Unclassified }\end{array}$ & $\begin{array}{c}\text { 18. SECURITY CLASSIFICATION } \\
\text { OF THIS PAGE } \\
\text { Unclassified }\end{array}$ & $\begin{array}{c}\text { 19. SECURITY CLASSIFICATION } \\
\text { OF ABSTRACT } \\
\text { Unclassified }\end{array}$ \\
\hline
\end{tabular}

